\title{
Emerging Role of Podocalyxin in the Progression of Mature B-Cell Non-Hodgkin Lymphoma
}

\author{
Estíbaliz Tamayo-Orbegozo ${ }^{1}$, Laura Amo ${ }^{1}$, Javier Díez-García ${ }^{2}$, Elena Amutio ${ }^{3}$, Marta Riñón ${ }^{4}$, \\ Marta Alonso ${ }^{4}$, Paula Arana ${ }^{4}$, Natalia Maruri ${ }^{4}$ and Susana Larrucea ${ }^{4, *}$ \\ 1 Regulation of the Immune System Group, Biocruces Bizkaia Health Research Institute, Plaza de Cruces 12, \\ 48903 Barakaldo, Bizkaia, Spain; estitamayo@hotmail.com (E.T.-O.); laura_tpo@hotmail.com (L.A.) \\ 2 Microscopy Facility, Biocruces Bizkaia Health Research Institute, Plaza de Cruces 12, 48903 Barakaldo, \\ Bizkaia, Spain; JAVIER.DIEZGARCIA2@osakidetza.eus \\ 3 Blood Cancer Group, Biocruces Bizkaia Health Research Institute, Hospital Universitario Cruces, Plaza de \\ Cruces 12, 48903 Barakaldo, Bizkaia, Spain; MARIAELENA.AMUTIODIEZ@osakidetza.eus \\ 4 Regulation of the Immune System Group, Biocruces Bizkaia Health Research Institute, Hospital \\ Universitario Cruces, Plaza de Cruces 12, 48903 Barakaldo, Bizkaia, Spain; \\ MARTAMARIA.RINONMARTINEZ-GALLO@osakidetza.eus (M.R.); \\ MARTA.ALONSOVARELA@osakidetza.eus (M.A.); p.arana.berganza@gmail.com (P.A.); \\ NATALIA.MARURIMACHADO@osakidetza.eus (N.M.) \\ * Correspondence: slarrucea@osakidetza.eus
}

Received: 2 December 2019; Accepted: 6 February 2020; Published: 8 February 2020

\begin{abstract}
Mature B-cell non-Hodgkin lymphoma (B-NHL) constitutes a group of heterogeneous malignant lymphoproliferative diseases ranging from indolent to highly aggressive forms. Although the survival after chemo-immunotherapy treatment of mature B-NHL has increased over the last years, many patients relapse or remain refractory due to drug resistance, presenting an unfavorable prognosis. Hence, there is an urgent need to identify new prognostic markers and therapeutic targets. Podocalyxin (PODXL), a sialomucin overexpressed in a variety of tumor cell types and associated with their aggressiveness, has been implicated in multiple aspects of cancer progression, although its participation in hematological malignancies remains unexplored. New evidence points to a role for PODXL in mature B-NHL cell proliferation, survival, migration, drug resistance, and metabolic reprogramming, as well as enhanced levels of PODXL in mature B-NHL. Here, we review the current knowledge on the contribution of PODXL to tumorigenesis, highlighting and discussing its role in mature B-NHL progression.
\end{abstract}

Keywords: podocalyxin; B-cell non-Hodgkin lymphoma; cancer progression; metastasis; drug resistance; metabolic reprogramming

\section{Introduction}

Non-Hodgkin lymphoma (NHL) represents the most common hematological malignancy in adults worldwide and accounts for approximately $90 \%$ of all diagnosed lymphomas in western countries, with B cell-NHL (B-NHL) being more frequent (85\%-90\%) than T-cell or natural killer (NK)-cell NHL [1,2]. The incidence of NHL has experienced a constant increase in recent years and this disease represents the fifth to ninth most common cancer in the majority of countries worldwide [3]. B-NHL consists of a heterogeneous group of lymphoproliferative malignancies that arise from lymphoid tissue B cells at varying stages of maturation and can spread to other organs, encompassing more than 40 neoplasm subtypes both molecular and clinically different [4]. They are currently classified according to the 2016 revision of the World Health Organization (WHO) classification of lymphoid neoplasms based on cell linage and pathological, genetic, immunophenotypic, and clinical features [4]. 
Among mature B-NHL, diffuse large B-lymphoma, an aggressive type of NHL, and indolent follicular lymphoma comprise $65 \%$ of all NHL and predominate in adulthood [2,5]. Nevertheless, in children, the most common B-NHL is the highly aggressive B-cell neoplasm Burkitt lymphoma [6]. Other mature B-NHLs include chronic lymphocytic leukemia/small lymphocytic lymphoma, mantle cell lymphoma, marginal zone B-cell lymphoma, hairy cell leukemia, and lymphoplasmacytic lymphoma/Waldenström macroglobulinemia [4].

Although the survival in patients with B-NHL has improved significantly during the past two decades since the introduction of anti-CD20 monoclonal antibodies to the standard chemotherapy regimens, many patients are refractory or relapse after treatment due to the acquisition of drug resistance that limits its effectiveness $[7,8]$. A better understanding of the molecular mechanism governing B-NHL development and chemo-immunotherapy resistance would allow the design of more efficient therapeutic drugs.

PODXL, also known as podocalyxin-like protein 1, PCLP1, PCLP, PC, GCTM-2 antigen, Gp135, or GP200, is a transmembrane protein belonging to the CD34 family of sialomucins and is expressed in multiple normal cell types including podocytes, vascular endothelium, platelets, hematopoietic progenitors, embryonic stem cells, and a subset of neurons [9-15]. PODXL is connected to the actin cytoskeleton through interaction with ezrin and $\mathrm{Na}^{+} / \mathrm{H}^{+}$-exchanger regulatory factor (NHERF) [16]. Depending on the cellular context, PODXL functions as an anti-adhesive or a pro-adhesive molecule [17-19]. PODXL was originally reported as the major apical sialoglycoprotein on kidney glomerular podocytes, where it exerts an anti-adhesive effect that maintains the filtration slits opened by charge repulsion as a result of its highly negative charge $[9,17,20,21]$. On the contrary, PODXL acts as a pro-adhesive molecule in high endothelial venules, interacting with L-selectin expressed on lymphocytes, suggesting a role for PODXL in lymphocyte recruitment to secondary lymphoid organs [18].

A growing number of studies have implicated PODXL in the development and progression of cancer. Elevated expression of PODXL has been associated with a more aggressive phenotype and poor patient clinical outcome in a variety of human solid cancers [22-26]. Thus far, limited studies have addressed the expression and function of PODXL in hematological neoplasms. PODXL has been found upregulated in mature B-NHL [27] and in blasts from patients with acute lymphoblastic and myeloid leukemia $[28,29]$. In Burkitt lymphoma cells, PODXL has recently emerged as a molecule that promotes cell proliferation, survival, migration, resistance to chemo-immunotherapy, and metabolism reprogramming [27]. The objective of this review is to summarize the current knowledge on the role of PODXL in tumorigenesis, discussing its contribution to the development of mature B-NHL.

\section{PODXL Expression and Regulation in Human Malignancies}

Expression of PODXL has been detected in numerous human solid malignancies including testicular cancer [30-32], breast cancer [22], pancreatic ductal adenocarcinoma [33-35], malignant astrocytic tumors [36], lung carcinoma [37,38], undifferentiated thyroid carcinoma [39], renal cell carcinoma [26], colorectal cancer [23,40-42], ovarian carcinoma [25], uterine endometrioid adenocarcinoma [43], urothelial bladder cancer [44], glioblastoma multiforme [45], oral squamous cell carcinoma [46,47], hepatocellular carcinoma [48], gastric cancer [49-52], esophageal carcinoma [50], and prostate cancer [53], as well as in hematological malignancies [27-29]. Furthermore, increased PODXL expression has been associated with high-grade tumors and poor clinical outcome in breast cancer [22], colorectal cancer [23,40,42,54], pancreatic ductal adenocarcinoma [35], ovarian cancer [25], renal cell carcinoma [26], urothelial bladder cancer [44,55], glioblastoma multiforme [45], gastric cancer [49-52], uterine endometrioid adenocarcinoma [43], periampullary adenocarcinoma [56], and esophageal adenocarcinoma [50].

Regarding hematological cancers, the detection of PODXL in normal human hematopoietic cells [57], as well as of Wilms' tumor antigen 1 (WT1), a transcriptional activator of PODXL, in blast cells of the majority of acute myeloid leukemia and acute lymphoblastic leukemia patients [58], 
prompted the determination of PODXL in leukemia [28,29]. An immunochemical analysis performed in blasts from 81 patients with leukemia showed elevated levels of PODXL expression in 77\% of cases of acute myeloid leukemia, $81 \%$ of cases of acute lymphoblastic leukemia, and $87 \%$ of cases of cutaneous myeloid sarcoma [28], which is a rare extramedullary tumor most often associated with acute myeloid leukemia [59]. Another report revealed by flow cytometry moderate levels of PODXL expression in 15 cases and high levels in 13 cases from a cohort of 73 patients with acute myeloid leukemia, and associated PODXL expression in leukemic blasts with a monocytic immunophenotype, a subtype characterized by poor clinical outcome and short survival [29]. Moreover, the cases of acute myeloid leukemia expressing higher levels of PODXL also displayed increased blast cell counts and higher levels of markers associated with unfavorable prognosis [29]. High levels of PODXL expression were also detected by immunohistochemistry in most of the bone marrow samples obtained from acute myeloid lymphoma patients compared to samples from normal subjects [60].

More recently, we have determined PODXL cell surface expression in malignant cells from a small cohort of patients with B-NHL and in B-NHL cell lines [27]. We found three- to eight-fold higher levels of PODXL expression in malignant cells compared to their normal B-cell counterparts in two out of five cases of follicular lymphoma and one out of three cases of chronic lymphocytic leukemia/small lymphocytic lymphoma. However, no expression of PODXL was observed in two cases of hairy cell leukemia and one case of Waldenström macroglobulinemia [27]. Furthermore, elevated levels of PODXL expression were detected on Raji Burkitt lymphoma cell line and moderate levels on Karpas 422 diffuse large B-cell lymphoma cell line. By contrast, Ramos and Daudi Burkitt lymphoma, Pfeiffer diffuse large B-cell lymphoma, and Karpas 1718 splenic marginal zone lymphoma cell lines showed no expression of PODXL [27].

Human PODXL protein is encoded by PODXL, a gene located on chromosome 7q32.3 [61]. A study identified a locus on chromosome 7q32-q33 associated with aggressive forms of prostate cancer using linkage analysis and allelic imbalance techniques [62]. Furthermore, a variable in-frame deletion and a missense variant of PODXL were associated with increased risk of prostate and tumor aggressiveness [24]. Interestingly, gain of 7q32.3-q33 region has been shown to predict the risk of disease transformation in patients with aggressive forms of follicular lymphoma [63]. Similarly, a comparative genomic hybridization study involving 46 patients diagnosed with Burkitt lymphoma detected gains on 7q31-q36 or 7q32-q36 regions in three patients and identified the association of gains on $7 q$ with an adverse prognosis [64]. Hence, the increased PODXL levels detected in malignant cells of B-NHL patients and in B-cell lines from our study might be caused by copy number gains of PODXL gene or gain mutations.

PODXL expression is positively regulated by WT1 [65] and specific protein 1 (SP1) [66]. WT1, a potent transcriptional regulator of several genes involved in growth, cellular metabolism, and renal differentiation, is highly expressed in many cancers, including hematological malignancies [67]. SP1 plays an important role in several physiological processes such as cell cycle, growth control, apoptosis, angiogenesis, and tumor cell metabolism [68].

PODXL expression can be repressed by some regulatory factors, including tumor suppressor p53 [69], particularly interesting new cysteine-rich protein 1 (PINCH1) [70], and Kruppel-like factor 4 (KLF4) [51]. PINCH1 is an adaptor protein that controls integrin-mediated cell adhesion, migration and epithelial-mesenchymal transition (EMT) and that acts as a transcriptional suppressor of PODXL in podocytes by interacting and inhibiting WT1-induced PODXL expression [70]. KLF4, a member of the KLF family of zinc finger transcription factors that regulates cell proliferation, differentiation, and survival, represses PODXL expression in human gastric cancer cells by directly binding to the 5'UTR of PODXL [51].

Additionally, epigenetic processes such as DNA methylation and the synthesis of specific microRNAs contribute to the modulation of PODXL expression. The in vitro CpG methylation of PODXL promoter resulted in a drastic reduction of its activity in human embryonic kidney (HEK293) cells [66]. In oral squamous cell carcinoma cell lines, hypomethylation of PODXL promoter has 
been associated with aggressiveness [46]. MicroRNAs are small noncoding RNAs that control gene expression post-transcriptionally, and their levels are frequently altered in many tumors, acting both as oncogenes and tumor suppressors. A study showed that miR199b, a microRNA targeting PODXL and DDR1 (discoidin domain receptor 1), regulates the expression of PODXL in K562 chronic myeloid leukemia cell line overexpressing miR-199b and established an inverse correlation between miR199b levels and PODXL expression in patients with acute myeloid leukemia [60]. In another report, the analysis of molecular and clinical data of 166 patients with acute myeloid leukemia from The Cancer Genome Atlas revealed a correlation between low expression of PODXL-targeting miR-199b and poor survival outcome [71]. Regarding B-cell lymphomas, various epigenetic mechanisms have been implicated in the development of these malignancies, including dysregulation of DNA methylation and histone modifications, as well as aberrant expression of microRNAs [72]. Among the most common microRNAs, miR-155, miR-17-92 cluster, miR-21, and miR-217 have been reported to function as oncogenes and miR-181a, miR-34a, miR146a, Cluster miR-15a/16-1, and miR-28 as tumor suppressor genes in B-cell lymphomas [73]. A univariate survival analysis performed in 64 diffuse large B-cell lymphoma patients showed an association of miR-199b expression with a better prognosis and with the germinal center B cell-like (GCB) subtype [74], known to confer a more favorable outcome than the activated $B$ cell-like (ABC) subtype.

\section{PODXL in Cancer Cell Survival, Proliferation, and Stemness}

The contribution of PODXL to human cancer progression has been demonstrated in a variety of cancer cells by gain- and loss-of-function studies, although the underlying mechanisms remain poorly understood (Table 1). 
Table 1. Role of podocalyxin (PODXL) in human cancer progression.

\begin{tabular}{|c|c|c|c|c|}
\hline \multicolumn{5}{|c|}{ Survival-Proliferation-Stemness } \\
\hline Tumor Cell Type & Cell Line Model & Method & Biological Effect and Mechanism & Ref. \\
\hline \multirow{5}{*}{ Glioblastoma multiforme } & JHU-0879 & Silencing of PODXL & Decreased proliferation and tumorsphere formation & [45] \\
\hline & \multirow[t]{2}{*}{$\begin{array}{l}\text { LN-299; } \\
\text { U-118 MG }\end{array}$} & $\begin{array}{l}\text { Ectopic overexpression of } \\
\text { PODXL }\end{array}$ & $\begin{array}{l}\text { Increased proliferation and } c-M Y C \text { and } c-J U N \text { mRNA } \\
\text { levels (by increasing beta-catenin signaling through the } \\
\text { p38 MAPK/GSK3B pathway) }\end{array}$ & \multirow[t]{2}{*}{ [75] } \\
\hline & & Silencing of PODXL & Decreased proliferation & \\
\hline & \multirow{2}{*}{$\begin{array}{l}\text { LN-299; } \\
\text { U-118 MG }\end{array}$} & $\begin{array}{l}\text { Ectopic overexpression of } \\
\text { PODXL }\end{array}$ & $\begin{array}{l}\text { Increased proliferation (by inhibiting Ang-(1-7)/Mas } \\
\text { signaling through a PI3K dependent mechanism) }\end{array}$ & \multirow[t]{2}{*}{ [76] } \\
\hline & & Silencing of PODXL & Decreased proliferation & \\
\hline \multirow{7}{*}{ Gastric cancer } & BGC823 & $\begin{array}{l}\text { Ectopic overexpression of } \\
\text { PODXL }\end{array}$ & Increased colony formation & \multirow[t]{2}{*}[77]{} \\
\hline & MGC803 & Silencing of PODXL & Decreased colony formation & \\
\hline & \multirow{4}{*}{ SGC-7901 } & $\begin{array}{l}\text { Ectopic overexpression of } \\
\text { PODXL }\end{array}$ & $\begin{array}{c}\text { Increased cell proliferation, colony formation and } \\
\text { activation of PI3K/AKT, NF-kb, MAPK (through } \\
\text { interaction with RUFY1) } \\
\text { Decreased apoptosis }\end{array}$ & \multirow[t]{4}{*}{ [52] } \\
\hline & & Silencing of PODXL & $\begin{array}{c}\text { Decreased cell proliferation, colony formation and } \\
\text { activation of PI3K/AKT, NF-kb, MAPK } \\
\text { Increased apoptosis }\end{array}$ & \\
\hline & & $\begin{array}{l}\text { Ectopic overexpression of } \\
\text { PODXL/Mouse xenograft }\end{array}$ & $\begin{array}{l}\text { Increased tumor growth in vivo (through interaction with } \\
\text { RUFY1) }\end{array}$ & \\
\hline & & $\begin{array}{l}\text { Silencing of PODXL/Mouse } \\
\text { xenograft }\end{array}$ & Decreased tumorigenesis in vivo & \\
\hline & $\begin{array}{l}\text { SGC-7901; } \\
\quad \text { AGS }\end{array}$ & $\begin{array}{l}\text { Silencing of PODXL/ Mouse } \\
\text { xenograft }\end{array}$ & Decreased tumor growth in vivo & [51] \\
\hline
\end{tabular}


Table 1. Cont.

\begin{tabular}{|c|c|c|c|c|}
\hline \multicolumn{5}{|c|}{ Survival-Proliferation-Stemness } \\
\hline Tumor Cell Type & Cell Line Model & Method & Biological Effect and Mechanism & Ref. \\
\hline \multirow[t]{2}{*}{ Colon cancer } & HCT15 & Silencing of PODXL & $\begin{array}{l}\text { Decreased tumorsphere formation } \\
\text { Decreased TAZ, survivin, CTGF, cyclinD1, and } \\
\text { stem-cell-related gene expression }\end{array}$ & [54] \\
\hline & $\begin{array}{l}\text { HCT116; } \\
\text { LOVO }\end{array}$ & Silencing of PODXL & $\begin{array}{l}\text { Decreased proliferation and clonogenic potential } \\
\text { Increased apoptosis and caspase- } 3 \text { and caspase- } 9 \text { expression }\end{array}$ & [78] \\
\hline \multirow{3}{*}{$\begin{array}{l}\text { Oral squamous cell } \\
\text { carcinoma }\end{array}$} & SAS & Silencing of PODXL & Decreased proliferation and colony formation & [46] \\
\hline & \multirow{2}{*}{ HSC-2 } & Silencing of PODXL & Decreased proliferation & \multirow{2}{*}{ [79] } \\
\hline & & $\begin{array}{c}\text { Silencing of PODXL/mouse } \\
\text { xenograft }\end{array}$ & Decreased tumor growth in vivo & \\
\hline \multirow{8}{*}{ Breast cancer } & MCF-7 & $\begin{array}{l}\text { Ectopic overexpression of } \\
\text { PODXL }\end{array}$ & Increased formation of tumorspheres & \multirow{3}{*}{ [80] } \\
\hline & \multirow[t]{2}{*}{ MDA-MB-231 } & Silencing of PODXL & $\begin{array}{c}\text { No effect on cell proliferation under adherent culture } \\
\text { conditions } \\
\text { Decreased formation of tumorspheres }\end{array}$ & \\
\hline & & $\begin{array}{c}\text { Silencing of PODXL/Mouse } \\
\text { xenograft }\end{array}$ & $\begin{array}{c}\text { Decreased primary tumor growth, invasion and distant } \\
\text { metastasis, in vivo }\end{array}$ & \\
\hline & \multirow{2}{*}{$\begin{array}{l}\text { MDA-MB-231 (clone 4175); } \\
\text { NAMEC8R }\end{array}$} & Silencing of PODXL & No effect on cell proliferation under culture conditions & \multirow{3}{*}{ [81] } \\
\hline & & $\begin{array}{c}\text { Silencing of PODXL/Mouse } \\
\text { xenograft }\end{array}$ & No effect on primary tumor growth in vivo & \\
\hline & MCF-7 & $\begin{array}{l}\text { Ectopic overexpression of } \\
\text { PODXL }\end{array}$ & Increased formation of tumorspheres & \\
\hline & \multirow{2}{*}{ MDA-MB-231 } & Silencing of PODXL & No effect on cell proliferation under culture conditions & \multirow{2}{*}{ [82] } \\
\hline & & $\begin{array}{c}\text { Silencing of PODXL/Mouse } \\
\text { xenograft }\end{array}$ & Decreased primary tumor growth & \\
\hline Pancreatic cancer & $\begin{array}{l}\text { SW1990; } \\
\text { Pa03c }\end{array}$ & $\begin{array}{c}\text { Silencing of PODXL/Mouse } \\
\text { xenograft }\end{array}$ & No effect on primary tumor growth in vivo & [83] \\
\hline Burkitt lymphoma & Raji & $\begin{array}{l}\text { Ectopic overexpression of } \\
\text { PODXL }\end{array}$ & Increased proliferation and colony formation & [27] \\
\hline
\end{tabular}


Table 1. Cont.

\begin{tabular}{|c|c|c|c|c|}
\hline & & Metastasis & & \\
\hline Tumor Cell Type & Cell Line Model & Method & Biological Effect and Mechanism & Ref. \\
\hline \multirow{4}{*}{ Glioblastoma multiforme } & \multirow[t]{2}{*}{$\begin{array}{l}\text { LN-299; } \\
\text { U-118 MG }\end{array}$} & $\begin{array}{l}\text { Ectopic overexpression of } \\
\text { PODXL }\end{array}$ & $\begin{array}{l}\text { Increased invasion and MMP-9 expression and activation (by } \\
\text { inhibiting Ang-(1-7)/Mas signaling through a PI3K dependent } \\
\text { mechanism) }\end{array}$ & \multirow[t]{2}{*}[76]{} \\
\hline & & Silencing of PODXL & Decreased invasion & \\
\hline & \multirow{2}{*}{$\begin{array}{l}\text { LN-299; } \\
\text { U-118 MG }\end{array}$} & $\begin{array}{l}\text { Ectopic overexpression of } \\
\text { PODXL }\end{array}$ & $\begin{array}{c}\text { Increased invasion (by increasing beta-catenin signaling } \\
\text { through p38 MAPK pathway) }\end{array}$ & \multirow[t]{2}{*}[75]{} \\
\hline & & Silencing of PODXL & Decreased invasion & \\
\hline \multirow{6}{*}{ Gastric cancer } & \multirow[t]{2}{*}{$\begin{array}{l}\text { SGC-7901; } \\
\quad \text { AGS }\end{array}$} & Silencing of PODXL & $\begin{array}{l}\text { Decreased migration and invasion } \\
\text { Decreased expression of MMP-2 }\end{array}$ & \multirow[t]{2}{*}[51]{} \\
\hline & & $\begin{array}{l}\text { Silencing of PODXL/Mouse } \\
\text { xenograft }\end{array}$ & Decreased liver metastasis, in vivo & \\
\hline & \multirow{2}{*}{$\begin{array}{l}\text { SGC-7901; } \\
\quad \text { AGS }\end{array}$} & $\begin{array}{l}\text { Ectopic overexpression of } \\
\text { PODXL }\end{array}$ & Increased migration and invasion & \multirow[t]{2}{*}[52]{} \\
\hline & & Silencing of PODXL & Decreased migration and invasion & \\
\hline & BGC823 & $\begin{array}{l}\text { Ectopic overexpression of } \\
\text { PODXL }\end{array}$ & Increased migration and invasion & \multirow[t]{2}{*}[77]{} \\
\hline & MGC803 & Silencing of PODXL & Decreased migration and invasion & \\
\hline \multirow{2}{*}{ Colon cancer } & HCT116; LOVO & Silencing of PODXL & Decreased migration and invasion & [78] \\
\hline & HCT15 & Silencing of PODXL & Decreased migration and invasion & {$[54]$} \\
\hline $\begin{array}{l}\text { Oral squamous cell } \\
\text { carcinoma }\end{array}$ & SAS & Silencing of PODXL & $\begin{array}{c}\text { Decreased migration and invasion } \\
\text { Inhibition of FAK activation and filopodia and invadopodia } \\
\text { formation }\end{array}$ & [46] \\
\hline
\end{tabular}


Table 1. Cont.

\begin{tabular}{|c|c|c|c|c|}
\hline & & Metastasis & & \\
\hline Tumor Cell Type & Cell Line Model & Method & Biological Effect and Mechanism & Ref. \\
\hline \multirow{12}{*}{ Breast cancer } & MCF-7 & $\begin{array}{l}\text { Ectopic overexpression of } \\
\text { PODXL }\end{array}$ & Perturbation of cell-cell junctions & [22] \\
\hline & \multirow[t]{2}{*}{ MCF-7 } & $\begin{array}{l}\text { Ectopic overexpression of } \\
\text { PODXL }\end{array}$ & $\begin{array}{l}\text { Increased collective migration in 2-D culture (dependent on } \\
\text { ezrin) } \\
\text { Increased collective budding and invasion in 3-D culture } \\
\text { (dependent on actomyosin) }\end{array}$ & \multirow[t]{2}{*}[84]{} \\
\hline & & $\begin{array}{l}\text { Ectopic overexpression of } \\
\text { PODXL/Mouse xenograft }\end{array}$ & Increased collective invasion and tumor budding, in vivo & \\
\hline & MCF-7 & $\begin{array}{c}\text { Ectopic overexpression of } \\
\text { PODXL }\end{array}$ & $\begin{array}{c}\text { Increased migration and invasion, matrix metalloproteinases } \\
1 \text { and } 9 \text { expression, MAPK and PI3K activity (by interacting } \\
\text { with ezrin) }\end{array}$ & [85] \\
\hline & MCF-7 & $\begin{array}{l}\text { Ectopic overexpression of } \\
\text { PODXL }\end{array}$ & $\begin{array}{l}\text { Increased invadopodia formation (through } \\
\text { Rac1/Cdc42/cortactin signaling) }\end{array}$ & \multirow{3}{*}{ [82] } \\
\hline & \multirow{2}{*}{ MDA-MB-231 } & Silencing of PODXL & Decreased invadopodia formation & \\
\hline & & $\begin{array}{c}\text { Silencing of PODXL/Mouse } \\
\text { xenograft }\end{array}$ & Decreased distant metastasis, in vivo & \\
\hline & MDA-MB-231 & $\begin{array}{c}\text { Silencing of PODXL/Mouse } \\
\text { xenograft }\end{array}$ & Decreased invasion and distant metastasis, in vivo & [80] \\
\hline & \multirow{2}{*}{$\begin{array}{l}\text { MDA-MB-231 (clone 4175); } \\
\text { NAMEC8R }\end{array}$} & Silencing of PODXL & $\begin{array}{l}\text { Decreased in vitro extravasation } \\
\text { Decreased migration. No effect on invasion }\end{array}$ & \multirow{4}{*}{ [81] } \\
\hline & & $\begin{array}{c}\text { Silencing of PODXL/mouse } \\
\text { xenograft }\end{array}$ & Decreased lung metastasis, in vivo & \\
\hline & \multirow[t]{2}{*}{ HMLER } & $\begin{array}{l}\text { Ectopic overexpression of } \\
\text { PODXL }\end{array}$ & Increased in vitro extravasation & \\
\hline & & $\begin{array}{l}\text { Ectopic overexpression of } \\
\text { PODXL/chick CAM assay }\end{array}$ & Increased in vivo extravasation & \\
\hline Prostate cancer & $\mathrm{P} 3 \mathrm{C}$ & $\begin{array}{l}\text { Ectopic overexpression of } \\
\text { PODXL }\end{array}$ & $\begin{array}{c}\text { Increased migration and invasion, matrix MMP-1 and MMP-9 } \\
\text { expression, MAPK and PI3K activity (by interacting with } \\
\text { ezrin) }\end{array}$ & [85] \\
\hline
\end{tabular}


Table 1. Cont.

\begin{tabular}{|c|c|c|c|c|}
\hline \multicolumn{5}{|c|}{ Metastasis } \\
\hline Tumor Cell Type & Cell Line Model & Method & Biological Effect and Mechanism & Ref. \\
\hline \multicolumn{5}{|c|}{ Resistance to Drugs } \\
\hline Tumor Cell Type & Cell Line Model & Method & Biological Effect and Mechanism & Ref. \\
\hline Colon cancer & HCT15 & Silencing of PODXL & Increased sensitivity to 5 -fluorouracil and to irinotecan & [54] \\
\hline \multirow[t]{2}{*}{ Osteosarcoma } & \multirow{2}{*}{$\begin{array}{l}\text { MG-63; } \\
\text { U2OS }\end{array}$} & $\begin{array}{l}\text { Ectopic overexpression of } \\
\text { PODXL }\end{array}$ & Increased resistance to cisplatin (by PI3K/AKT pathway) & \multirow[t]{2}{*}{88} \\
\hline & & Silencing of PODXL & Increased sensitivity to cisplatin & \\
\hline \multirow{2}{*}{$\begin{array}{l}\text { Oral tongue squamous } \\
\text { carcinoma }\end{array}$} & \multirow{2}{*}{$\begin{array}{l}\text { SCC-4; } \\
\text { Tca } 8113\end{array}$} & $\begin{array}{l}\text { Ectopic overexpression of } \\
\text { PODXL }\end{array}$ & $\begin{array}{l}\text { Increased resistance to cisplatin (by increasing BMI-1 and } \\
\text { FAK) }\end{array}$ & \multirow[t]{2}{*}[89]{} \\
\hline & & Silencing of PODXL & Increased sensitivity to cisplatin & \\
\hline \multirow[t]{2}{*}{ Astrocytoma } & SW1783 & $\begin{array}{l}\text { Ectopic overexpression of } \\
\text { PODXL }\end{array}$ & Increased resistance to temozolomide (by PI3K/AKT pathway) & \multirow[t]{2}{*}[90]{} \\
\hline & $\mathrm{U}-87$ & Silencing of PODXL & Increased sensitivity to temozolomide & \\
\hline Burkitt lymphoma & Raji & $\begin{array}{l}\text { Ectopic overexpression of } \\
\text { PODXL }\end{array}$ & Increased resistance to dexamethasone and obinutuzumab & [27] \\
\hline \multicolumn{5}{|c|}{ Cancer Cell Metabolism } \\
\hline Tumor Cell Type & Cell Line Model & Method & Biological Effect and Mechanism & Ref. \\
\hline Burkitt lymphoma & Raji & $\begin{array}{l}\text { Ectopic overexpression of } \\
\text { PODXL }\end{array}$ & $\begin{array}{l}\text { Increased lipogenesis, PPP, glutaminolysis, and glutamine } \\
\text { dependence; decreased glucose dependence }\end{array}$ & [27] \\
\hline
\end{tabular}


Table 1. Cont.

\begin{tabular}{|c|c|c|c|c|}
\hline \multicolumn{5}{|c|}{ Metastasis } \\
\hline Tumor Cell Type & Cell Line Model & Method & Biological Effect and Mechanism & Ref. \\
\hline \multicolumn{5}{|c|}{ Resistance to Drugs } \\
\hline Tumor Cell Type & Cell Line Model & Method & Biological Effect and Mechanism & Ref. \\
\hline Colon cancer & HCT15 & Silencing of PODXL & Increased sensitivity to 5 -fluorouracil and to irinotecan & [54] \\
\hline \multirow[t]{2}{*}{ Osteosarcoma } & \multirow{2}{*}{$\begin{array}{l}\text { MG-63; } \\
\text { U2OS }\end{array}$} & $\begin{array}{l}\text { Ectopic overexpression of } \\
\text { PODXL }\end{array}$ & Increased resistance to cisplatin (by PI3K/AKT pathway) & \multirow[t]{2}{*}{ [88] } \\
\hline & & Silencing of PODXL & Increased sensitivity to cisplatin & \\
\hline \multirow{2}{*}{$\begin{array}{l}\text { Oral tongue squamous } \\
\text { carcinoma }\end{array}$} & \multirow{2}{*}{$\begin{array}{l}\text { SCC-4; } \\
\text { Tca } 8113\end{array}$} & $\begin{array}{l}\text { Ectopic overexpression of } \\
\text { PODXL }\end{array}$ & $\begin{array}{l}\text { Increased resistance to cisplatin (by increasing BMI-1 and } \\
\text { FAK) }\end{array}$ & \multirow[t]{2}{*}{ [89] } \\
\hline & & Silencing of PODXL & Increased sensitivity to cisplatin & \\
\hline \multirow[t]{2}{*}{ Astrocytoma } & SW1783 & $\begin{array}{l}\text { Ectopic overexpression of } \\
\text { PODXL }\end{array}$ & Increased resistance to temozolomide (by PI3K/AKT pathway) & \multirow[t]{2}{*}{ [90] } \\
\hline & U-87 & Silencing of PODXL & Increased sensitivity to temozolomide & \\
\hline Burkitt lymphoma & Raji & $\begin{array}{l}\text { Ectopic overexpression of } \\
\text { PODXL }\end{array}$ & Increased resistance to dexamethasone and obinutuzumab & [27] \\
\hline \multicolumn{5}{|c|}{ Cancer Cell Metabolism } \\
\hline Tumor Cell Type & Cell Line Model & Method & Biological Effect and Mechanism & Ref. \\
\hline Burkitt lymphoma & Raji & $\begin{array}{l}\text { Ectopic overexpression of } \\
\text { PODXL }\end{array}$ & $\begin{array}{l}\text { Increased lipogenesis, PPP, glutaminolysis, and glutamine } \\
\text { dependence; decreased glucose dependence }\end{array}$ & [27] \\
\hline
\end{tabular}


A role for PODXL in tumor cell proliferation was first evidenced in JHU-0879 glioblastoma multiforme stem-like cell line after silencing of PODXL with specific short hairpin RNAs (shRNAs), which resulted in a significant reduction in cell proliferation and oncosphere formation [45]. In LN-299 and U-118 MG human glioblastoma multiforme cells, ectopic overexpression of PODXL increased soluble/intracellular beta-catenin levels and induced mRNA expression of the beta-catenin signaling target genes $c-M Y C$ and $c$-JUN and cell proliferation through a mechanism dependent on p38 mitogenand beta-catenin signaling [75]. Moreover, PODXL increased the level of inhibitory phosphorylation of glycogen synthase kinase-3B (GSK3B) via activation of p38 mitogen-activated protein kinase (MAPK), indicating that PODXL enhances glioblastoma multiforme proliferation by increasing the soluble beta-catenin level/beta-catenin signaling through a mechanism dependent on p38 MAPK/GSK3B pathway [75]. PODXL has also been found to induce proliferation in LN-299 and U-118 MG glioblastoma multiforme cells by inhibiting angiotensin-(1-7)/Mas signaling, known to abrogate growth in many cancer cells [76].

The contribution of PODXL to gastric cancer proliferation has been demonstrated in several studies. In BGC823 and MGC803 gastric cancer cells, PODXL promoted colony formation [77]. Additionally, PODXL in SGC-7901 gastric cancer cells favored proliferation and colony formation, abrogated cell apoptosis, activated phosphatidylinositol 3-kinase (PI3K)/AKT, MAPK/ERK, and NF-kB signaling pathways, and promoted tumorigenesis in a mouse xenograft model through a mechanism dependent on RUN and FYVE domain containing 1 (RUFY1) [52]. The PI3K/AKT pathway is one of the most commonly activated drivers of cancer and promotes tumor initiation and progression [91,92]. PODXL in SGC-7901 and AGS gastric cancer cells also enhanced primary tumor growth in nude mice [51]. In HCT15 colorectal cells, knockdown of PODXL reduced the expression of TAZ protein, its downstream targets survivin, connective tissue growth factor (CTGF), CYR61 and cyclinD1, and stem-cell-related genes, as well as tumorsphere formation, indicating that PODXL plays a crucial role in self-renewal of colon cancer cells [54].

Knockdown of PODXL in HCT116 and LOVO colorectal cancer cell lines suppressed cell proliferation and clonogenic potential, promoted apoptosis, and increased protein levels of caspase-3 and caspase-9, pointing to a role for PODXL in cell survival [78].

In SAS human oral squamous cell carcinoma cell line, silencing of PODXL abrogated cell proliferation and colony formation [46]. This effect was corroborated in vivo by transplanting PODXL-silenced HSC-2 oral squamous cell carcinoma cell line into nude mice, which resulted in both tumor volume and tumor weight reduction compared to that derived from parental HSC-2 cells [79].

Contrasting with these data, in the breast cancer cell lines MDA-MB-231, the highly aggressive MDA-MB-231 clone 4175 and NAMEC8R, all expressing high levels of endogenous PODXL, silencing of PODXL exerted no effect on cell proliferation under monolayer culture conditions [80-82]. However, the frequency of tumorsphere-forming cells was markedly decreased in PODXL-silenced MDA-MB-231 breast cancer cell line and, conversely, its overexpression in luminal-like MCF-7 breast cancer cell line, a low metastatic cell line expressing low levels of endogenous PODXL, resulted in increased tumorsphere formation [80]. Consistent with these results, silencing of PODXL in MDA-MB-231 cells reduced primary tumor growth in a mouse model xenograft [80,82]. Nevertheless, no effect of PODXL silencing on tumor growth was observed when the xenografted cell lines were MDA-MB-231 clone 4175 cells, NAMEC8R, or the pancreatic cancer cell lines SW1990 and Pa03c [81,83]. Of note, a monoclonal antibody that preferentially bound to PODXL expressed on human tumor cells delayed tumor growth and metastasis to the lung in a mouse model using MDA-MB-231 breast cancer cells [80]. All these data demonstrate the complex and crucial role of PODXL in tumor cell proliferation and tumorsphere formation in vitro as well as in primary tumor growth in vivo.

In Raji Burkitt lymphoma cells, we showed that ectopic overexpression of PODXL enhanced cell proliferation and colony formation [27]. Furthermore, overexpression of PODXL in Raji cells induced cell-to-cell adhesion, resulting in the formation of large cell aggregates, a process that was partially abolished by a specific antibody against integrin subunit beta2 [27]. Engagement of 
lymphocyte function-associated antigen 1 (LFA-1), an adhesion molecule belonging to the subgroup of beta2-integrins, with its ligand intercellular adhesion molecule 1 (ICAM-1) has been reported to inhibit apoptotic cell death in human DND-39 Burkitt lymphoma cell line [93].

\section{PODXL in Metastasis}

Metastasis is a complex and multistep process which involves tumor cell dissociation from the primary tumor, invasion of the surrounding extracellular matrix, intravasation through the endothelium into the bloodstream, and extravasation to secondary sites via attaching to endothelial cells and crossing the blood vessel walls. Finally, malignant cells survive and growth at these metastatic sites [94,95]. In order to invade and disseminate, tumor cells utilize dynamic actin-rich membrane protrusions named invadopodia which contain matrix proteases that degrade the extracellular matrix [94,96]. In contrast to metastasis of solid cancers, which requires the acquisition of a metastatic phenotype, lymphoma dissemination is thought to be driven by physiological mechanisms governing normal lymphocyte trafficking $[97,98]$. In any case, both metastasis and lymphoma dissemination involve the participation of a variety of adhesion molecules, including integrins and selectins, as well as chemokines [97,98].

Several studies provide evidence of a role for PODXL in cancer metastasis in vitro and in vivo (Table 1). In MCF-7 breast cancer cells, forced expression of PODXL perturbed cell-cell junctions, a process which could facilitate breast carcinoma invasion [22]. Additionally, PODXL has been shown to induce collective tumor migration and invasion, as well as tumor budding of MCF-7 cells both in vitro and in vivo [84]. Furthermore, in MCF-7 breast cancer and P3C prostate cancer cell lines, PODXL enhanced cell migration and invasion, matrix metalloproteinase 1 and 9 expression, and activation of MAPK and PI3K activity through its interaction with ezrin in in vitro assays [85]. In the highly aggressive MDA-MB-231 breast cancer cell line, suppression of PODXL decreased invadopodia formation and activation [82]. On the other hand, PODXL overexpression in MCF-7 breast cancer cell line stimulated invadopodia formation and activation, through the induction of Rac1/Cdc42/cortactin signaling [82]. The migratory and invasive properties promoted by PODXL has also been demonstrated in vitro in colorectal cancer (HCT116, LOVO and HCT15), gastric cancer (SGC-7901, AGS, BGC823, and MGC803), malignant testicular tumor (NT2), oral squamous cell carcinoma (SAS), lung adenocarcinoma (A549), and glioblastoma multiforme (LN-299 and U-118) cell lines [32,46,51,54,75-78,87]. Besides, silencing of PODXL in both NAMEC8R and the highly metastatic MDA-MB-231 4175 breast cancer cells decreased extravasation in vitro, an effect which was totally reversed by overexpressing wild type PODXL [81]. PODXL silencing also decreased the extravasation of MiaPaca2 and Panc1 pancreatic carcinoma cell lines [81].

A study reported that PODXL interacts with the chemokine receptor CXCR4 and promotes CXCL12-mediated migration of mouse primary hematopoietic cells [99]. CXCL12 is a chemokine produced by stromal cells of lymph nodes, bone marrow, liver, lung, and Peyer's plaques and involved in hematopoietic cell trafficking by binding to CXCR4 expressed on these cells [100]. The CXCL12/CXCR4 axis has been found to play a major role in tumor progression, metastasis, and survival [100,101]. High levels of CXCR4 expression have been detected in B-NHL with wide dissemination to lymph nodes and associated with poor clinical outcome [102-105]. Recently, we have demonstrated that overexpression of PODXL in Raji Burkitt lymphoma cells increased migration towards CXCL12 [27].

A critical event of metastatic dissemination to distant sites is the adhesion of circulating malignant cells to vascular endothelial cells [95]. Many studies point to a role for E-selectin displayed on vascular endothelial cells in the recruitment of tumor cells to metastatic sites in breast, bladder, gastric, pancreatic, and colorectal carcinoma, as well as hematological malignancies [95,106,107]. Interestingly, PODXL has been implicated in the interaction of tumor cells to E-selectin as well as to L-selectin [34]. Silencing of PODXL with specific shRNAs markedly reduced the binding of SW1990 pancreatic tumor cells to immobilized E- and L-selectin under physiological flow conditions, indicating a functional role for PODXL in this process [34]. 
The contribution of PODXL to tumor metastasis to distal sites has been elucidated in vivo in a few studies (Table 1). Overexpression of PODXL in HMLER cells enhanced cell extravasation in the chick CAM assay, an in vivo model for extravasation [81]. In NAMEC8R, MDA-MB-231, and MDA-MB-231 clone 4175 breast cancer cells, knockdown of PODXL significantly inhibited tumor dissemination to distant organs in murine xenograft models [80-82], an effect rescued by re-expressing wild type PODXL [81]. In SGC-7901 and AGS gastric cancer cells, silencing of PODXL impaired liver metastasis in nude mice [51]. Recently, depletion of PODXL has been found to reduce liver metastasis in a hemispleen mouse model using SW1990 and Pa03c pancreatic adenocarcinoma cells [83]. This study showed that the direct interaction of PODXL with the large GTP-ase dynamin-2 regulates cytoskeleton dynamics, promoting migration and metastasis of pancreatic cancer cells [83].

\section{PODXL in EMT}

Accumulating evidence supports a critical role of EMT process in driving tumor metastatic dissemination, drug resistance, and immunosuppression [81,108]. During EMT, epithelial cells lose their apical-basal polarity and cell-to-cell contacts, adopting a mesenchymal morphology and migratory and invasive properties [109]. Therefore, the contribution of PODXL to EMT process has been explored in some studies (Table 1). In A549 lung adenocarcinoma cell line, PODXL expression increased during transforming growth factor-beta (TGF-beta)-induced EMT [86], and PODXL silencing reduced morphological changes and molecular markers associated with EMT [86]. Accordingly, forced expression of PODXL in A549 cells promoted changes characteristic of EMT through a process dependent on the activation of PI3K/AKT signaling pathway [87]. Similarly, PODXL silencing in HCT15 colon cancer cells and in SGC-7901 and AGS gastric cancer cells led to a reduction of EMT-associated markers [51,54]. Moreover, the analysis of mRNA expression levels in patients with colon cancer using GSE17536 datasets revealed a positive correlation of PODXL expression with the mesenchymal markers vimentin, N-cadherin, TWIST2, SLUG, and ZEB1 and a negative correlation with the epithelial marker E-cadherin [54]. In a study performed in HMLER human mammary epithelial cells, activation of EMT program by Dox-inducible expression of the EMT transcription factors Snail or ZEB1 resulted in increased mRNA PODXL levels, indicating that PODXL is induced during EMT process [81]. Further, compared to HMLER cells, total and cell surface PODXL protein expression was shown to be upregulated in NAMEC8R cells, which are mammary mesenchymal epithelial cells that naturally arise from HMLER cells [81]. Nevertheless, overexpression of PODXL in HMLER cells did not induce EMT program, indicating that PODXL acts as an effector, but not as an activator, of the EMT program [81]. Interestingly, the authors also showed that PODXL promotes extravasation during EMT by directly engaging the cytoskeletal linker protein ezrin to establish the dorsal cortical polarity necessary for efficient transendothelial migration [81].

Although the role of EMT-related processes in non-epithelial cancers, including lymphoma and leukemia, remains largely unexplored, various EMT transcription factors have emerged as effectors of malignant progression in these diseases [110,111]. In patients with diffuse large B-cell lymphoma, ZEB1 expression has been associated with adverse clinical presentation and poor outcome [112]. More recently, ZEB1 has been shown to be upregulated in diffuse large B-cell lymphoma tissues and cell lines and involved in a positive feedback loop that promotes diffuse large B-cell lymphoma progression and immune evasion [113]. In mantle cell lymphoma patients, high expression levels of ZEB1 were correlated with shorter overall survival [114]. Moreover, knockdown of the EMT activator ZEB1 using specific shRNAs in Granta-519 and/or Jeko-1 mantle cell lymphoma cell lines reduced cell viability, proliferation, and drug resistance and greatly diminished tumor growth in mouse xenograft models, indicating the mediation of ZEB1 in mantle cell lymphoma progression [114].

\section{PODXL in Drug Resistance}

A few studies have examined the involvement of PODXL in tumor cell resistance to both conventional cytotoxic agents and immunotherapy drugs (Table 1). Knockdown of PODXL in 
HCT15 colon carcinoma cells markedly increased the sensitivity to 5-fluorouracil, an inhibitor of thymidylate synthase, and to irinotecan [54], a topoisomerase I inhibitor with reported clinical activity against relapsed or refractory B-NHL in combination chemotherapy $[115,116]$. Furthermore, enforced expression and PODXL silencing studies in MG-63 and U2OS osteosarcoma cell lines showed that PODXL induces cisplatin chemoresistance via PI3K/AKT signaling pathway [88]. Cisplatin is a chemotherapeutic drug effective against many types of cancers, including NHL [117]. In SCC-4 and Tca8113 oral tongue squamous carcinoma cell lines, PODXL conferred resistance to cisplatin by increasing mRNA stability and protein expression levels of B-cell-specific lymphoma Moloney murine leukemia virus integration site 1 homolog (BMI-1) by means of focal adhesion kinase (FAK) [89]. In SW1783 and U-87 astrocytoma cell lines, PODXL increased cell survival against apoptosis induced by temozolomide, a DNA-alkylating agent widely used as standard therapy for glioblastoma multiforme, through the up-regulation of PI3K/AKT signaling pathway [90]. Temozolomide has been proven to display clinical activity in patients with primary central nervous system lymphoma, a rare but aggressive extranodal NHL, most commonly of the B-cell subtype [118].

We have recently demonstrated that overexpression of PODXL in Raji Burkitt lymphoma cells decreases dexamethasone- and hydrogen peroxide-induced cell apoptosis [27]. Dexamethasone is a glucocorticoid included in several chemotherapy protocols for hematological malignancies such as B-cell lymphomas and leukemia, but prolonged use can lead to the development of drug resistance [119-121]. Glucocorticoids trigger lymphoma cell apoptosis through the generation of hydrogen peroxide [122], a reactive oxygen species that induces apoptosis and senescence [123]. We have also shown that forced expression of PODXL in Raji Burkitt lymphoma cells increased cell survival upon treatment with obinutuzumab [27], a novel type II glycoengineered humanized anti-CD20 monoclonal antibody with superior ability to induce direct, non-complement dependent cell death and enhanced antibody-dependent cellular cytotoxicity (ADCC) compared to rituximab [124,125]. Obinutuzumab induces cell death through a non-apoptotic mechanism mediated by lysosomes and dependent on actin reorganization [126].

\section{PODXL in Cancer Cell Metabolism}

Tumor cells upregulate the expression of nutrient transporters and alter their metabolism to increase the synthesis of proteins, lipids, nucleic acids, and bioenergetic molecules to foster their accelerated proliferation, as well as the production of redox molecules, to protect cells from apoptosis, leading to tumor dependency on specific nutrients [127]. Metabolic rearrangements also influence tumor metastasis, drug response and favor the escape from immune surveillance [128,129], representing potential therapeutic targets [130]. Tumor cells mainly utilize glucose as a primary nutrient source [127]. Numerous cancer cells also increase the rate of glutamine uptake and glutaminolysis for the generation of biosynthetic precursors, the activation of signaling pathways and the maintenance of mitochondria integrity $[131,132]$. In tumor cells deprived of glucose, glutamine serves as an alternative substrate for the generation of energy and biomolecules. Glutamine metabolism has been reported to play a crucial role in cell survival and proliferation under glucose-starved conditions in a MYC-inducible human Burkitt lymphoma cell line (P493) [133].

The participation of PODXL in cell metabolism remains unexplored. PODXL has been reported to upregulate and form a complex with the glucose-transporter 3 (GLUT3) in embryonal carcinoma cancer stem cells [134]. On the other hand, glucose has been found to modulate PODXL expression in both normal and malignant cells $[27,135,136]$. In HGEC human glomerular epithelial cells, the presence of high-glucose levels downregulated PODXL expression [135,136], which reverted to normal values after cell exposure to low-glucose conditions [136]. Accordingly, we observed that Raji Burkitt lymphoma cells cultured in low-glucose conditions $(0.5 \mathrm{mM})$ expressed increased surface levels of PODXL compared to those grown in high-glucose conditions (11 mM) [27].

Recently, we have uncovered a new function for PODXL as a metabolic reprogramming inducer in Raji Burkitt lymphoma cells [27]. As PODXL triggers both MAPK signaling pathway, known to enhance 
glutamine metabolism and cell growth [137], and PI3K/AKT signaling axis, a pathway that favors cell survival under glucose limiting conditions [138], we examined the role of PODXL in Raji cell glutamine metabolism [27]. We showed that under glucose-deprived conditions, Raji cells overexpressing PODXL exhibited enhanced cell proliferation, whereas in the absence of glutamine their proliferation decreased and total cell death augmented relative to that of Raji control cells [27]. Moreover, PODXL overexpression in Raji cells induced cell death in glutamine-deprived conditions [27]. Accordingly, the presence of Compound 968, a selective inhibitor of glutaminase 1 (GLS1), the first enzyme in glutaminolysis pathway, significantly diminished the proliferation of Raji cell overexpressing PODXL compared to that of Raji control cells [27]. Our results indicate that PODXL promotes glutaminolysis and glutamine dependence but decreases glucose dependence in Raji Burkitt lymphoma cells [27].

Dysregulation of lipid metabolism is considered a hallmark of cancer cells $[139,140]$. Tumor cells require fatty acids to generate new membranes, signaling molecules, and energy and store the excess as intracellular lipid droplets $[139,141]$. Increased expression of fatty acid synthase (FASN), the terminal and crucial enzyme in de novo lipogenesis, has been linked to tumor metastasis, chemoresistance, and reduced patient survival in many cancers $[142,143]$. Lipid metabolism, as well as enzymes involved in lipogenesis, including FASN, has been reported to be dysregulated in Burkitt lymphoma, resulting in the accumulation of multiple lipid vacuoles in the cytoplasm, a morphological characteristic of Burkitt lymphoma cells [144]. We have recently reported that forced expression of PODXL in Raji Burkitt lymphoma cells enhanced the formation of cytosolic lipid droplets [27]. Moreover, the addition of the FASN inhibitor cerulenin to the culture medium led to a reduced proliferation of Raji cells overexpressing PODXL compared to that of control cells, indicating that PODXL shifts the metabolism toward de novo fatty acid synthesis, thereby increasing the dependency of Raji cell proliferation on this pathway [27].

Growing evidence indicates that tumor cells divert glycolytic intermediaries into the pentose phosphate pathway (PPP) to generate both pentose phosphates, necessary for the synthesis of nucleotides that support high cell proliferation, and NADPH [145]. This metabolic pathway plays a pivotal role in tumor cell survival, proliferation, and chemoresistance and has been associated with tumor aggressiveness [145]. Accordingly, dysregulation of PPP enzymes such as glucose 6-phosphate dehydrogenase (G6PD), the first and rate-limiting enzyme of this pathway, has been reported to promote tumorigenesis [145]. Several cancer cells, including NHL, exhibit increased expression of G6PD as well as PPP flux, which is correlated with poor prognosis [146-148]. We have recently shown that in the presence of 6-aminonicotinamide, a competitive inhibitor of G6PD and PPP, Raji Burkitt lymphoma cells overexpressing PODXL proliferated to a lesser extent than control cells, indicating that PODXL induces PPP flux, becoming dependent on this pathway [27].

\section{Conclusions and Future Perspectives}

PODXL is overexpressed in various types of cancer and associated with tumor aggressiveness and poor prognosis. Several studies have reported a role for PODXL in regulating critical biological processes that promote tumor progression, including cell proliferation, survival, stemness, EMT, and metastasis, as well as resistance to drugs. In Burkitt lymphoma cells, PODXL induces cell proliferation, survival, clonogenicity, chemotaxis, and resistance to dexamethasone and obinutuzumab and reprograms tumor cell metabolism to maintain its high proliferative activity, yet the underlying molecular mechanisms remain unexplored (Figure 1). 


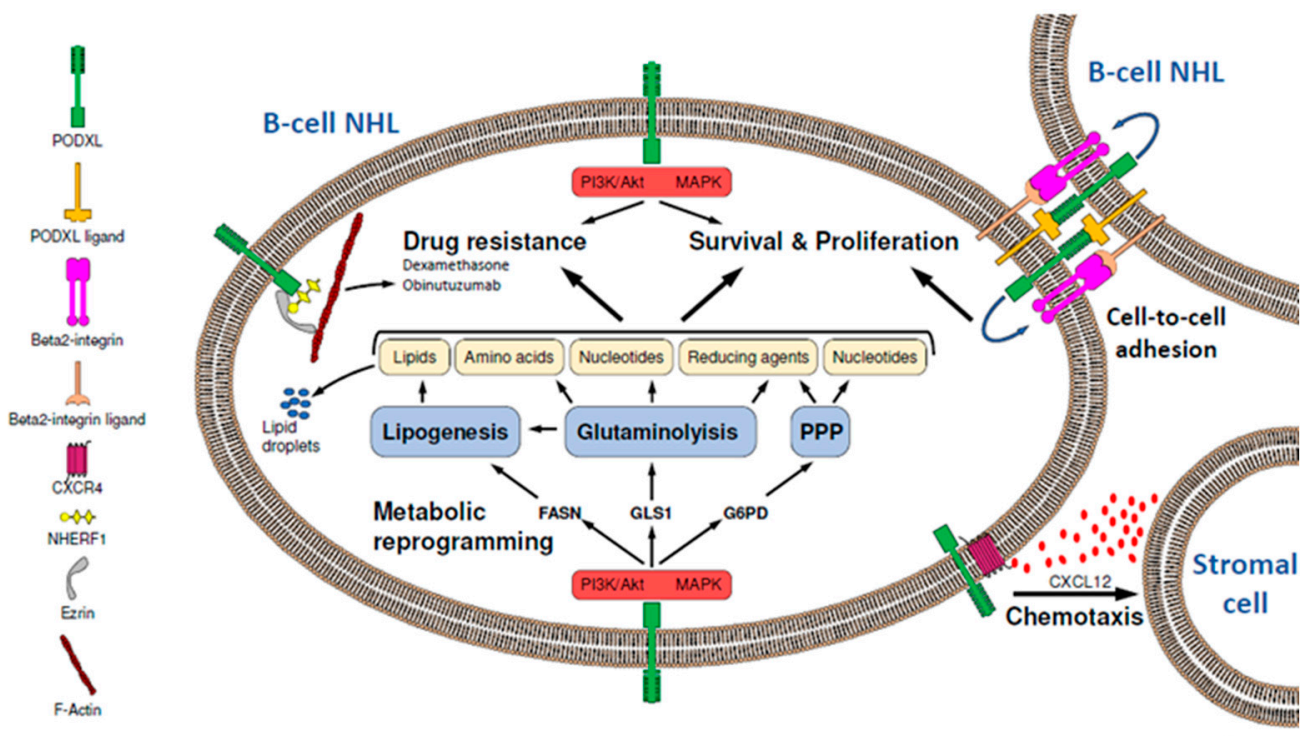

Figure 1. Schematic representation of the potential role of podocalyxin (PODXL) in mature B-cell non-Hodgkin lymphoma (B-NHL) progression. PODXL induces cell survival, proliferation, and drug resistance in mature B- NHL cells, likely through the activation of activated phosphatidylinositol 3-kinase (PI3K)/AKT and mitogen-activated protein kinase (MAPK) signaling pathways. Additionally, PODXL promotes glutaminolysis, lipogenesis, and pentose phosphate pathway via activation of glutaminase 1 (GLS1), fatty acid synthase (FASN), and glucose 6-phosphate dehydrogenase (G6PD), respectively, which would generate biomolecules and reducing agents necessary for tumor cell survival, proliferation, and drug resistance. This metabolic reprogramming may be mediated by PI3K/AKT and MAPK signaling pathways. The PODXL-induced B-NHL-resistance to obinutuzumab could be due to the capacity of PODXL to reorganize the actin cytoskeleton. In addition to this, PODXL favors cell-to-cell adhesion in B-NHL by a beta2-integrin-mediated process, which would lead to cell survival. PODXL also enhances chemotaxis of B-NHL cells towards C-X-C motif chemokine ligand 12 (CXCL12), which is released by stromal cells of distant sites and binds to C-X-C motif chemokine receptor 4 (CXCR4), a chemokine receptor that interacts with PODXL. NHERF1: $\mathrm{Na}^{+} / \mathrm{H}^{+}$-exchanger regulatory factor; PPP: pentose phosphate pathway.

Our knowledge on the role of PODXL in mature B-NHL progression is based on experiments conducted on a single Burkitt lymphoma cell line. Hence, it remains to be proven whether these findings also apply to other mature B-NHL subtypes. On the other hand, PODXL expression has been determined in malignant cells from a reduced cohort of patients with mature B-NHL. The analysis of a broad array of mature B-NHL samples would allow to establish whether stratification of patients according to PODXL expression predicts patients' survival and defines a novel subgroup of patients with unfavorable prognosis. PODXL might predict response to therapy, central nervous system relapse, or transformation of indolent follicular lymphoma to aggressive diffuse large B-cell lymphoma. Moreover, PODXL might constitute a potential therapeutic target for the treatment of B-NHL expressing this molecule. In this regard, the expression of tumor-specific PODXL glycoforms would allow the development of blocking antibodies with reduced undesirable side effects. Further studies are still required to decipher the biological function of PODXL in different subtypes of mature B-NHL and the molecular mechanism governing PODXL-induced mature B-NHL progression in order to determine the potential of PODXL as a therapeutic target.

Funding: This study has been funded by Instituto de Salud Carlos III through the project PI18/00629 (Co-funded by European Regional Development Fund; "A way to make Europe").

Conflicts of Interest: The authors declare no conflict of interest. 


\section{Abbreviations}

$\begin{array}{ll}\text { Abb. } & \text { Full Name } \\ \text { ADCC } & \text { Antibody-dependent cellular cytotoxicity } \\ \text { BMI-1 } & \text { B-cell-specific Moloney murine leukemia virus integration site 1 homolog } \\ \text { B-NHL } & \text { B-cell non-Hodgkin lymphoma } \\ \text { CXCR4 } & \text { C-X-C motif chemokine receptor 4 } \\ \text { CXCL12 } & \text { C-X-C motif chemokine ligand 12 } \\ \text { EMT } & \text { Epithelial-mesenchymal transition } \\ \text { FASN } & \text { Fatty acid synthase } \\ \text { G6PD } & \text { Glucose-6-phosphate dehydrogenase } \\ \text { GLUT3 } & \text { Glucose transporter 3 } \\ \text { GSK3B } & \text { Glycogen synthase kinase-3B } \\ \text { KLF4 } & \text { Kruppel-like factor 4 } \\ \text { MAPK } & \text { Mitogen-activated protein kinase } \\ \text { NHL } & \text { Non-Hodgkin lymphoma } \\ \text { PI3K } & \text { Phosphatidylinositol 3-kinase } \\ \text { PINCH1 } & \text { Particularly interesting new cysteine-histidine rich protein 1 } \\ \text { PODXL } & \text { Podocalyxin } \\ \text { PPP } & \text { Pentose phosphate pathway } \\ \text { shRNAs } & \text { Short hairpin RNAs } \\ \text { SP1 } & \text { Specific protein 1 } \\ \text { TGF-beta } & \text { Transforming growth factor-beta } \\ \text { WT1 } & \text { Wilms' tumor antigen 1 } \\ & \end{array}$

\section{References}

1. Shankland, K.R.; Armitage, J.O.; Hancock, B.W. Non-Hodgkin lymphoma. Lancet 2012, 380, $848-857$. [CrossRef]

2. Armitage, J.O.; Gascoyne, R.D.; Lunning, M.A.; Cavalli, F. Non-Hodgkin lymphoma. Lancet 2017, 390, 298-310. [CrossRef]

3. Miranda-Filho, A.; Pineros, M.; Znaor, A.; Marcos-Gragera, R.; Steliarova-Foucher, E.; Bray, F. Global patterns and trends in the incidence of non-Hodgkin lymphoma. Cancer Causes Control 2019, 30, 489-499. [CrossRef] [PubMed]

4. Swerdlow, S.H.; Campo, E.; Pileri, S.A.; Harris, N.L.; Stein, H.; Siebert, R.; Advani, R.; Ghielmini, M.; Salles, G.A.; Zelenetz, A.D.; et al. The 2016 revision of the World Health Organization classification of lymphoid neoplasms. Blood 2016, 127, 2375-2390. [CrossRef] [PubMed]

5. Sandlund, J.T.; Martin, M.G. Non-Hodgkin lymphoma across the pediatric and adolescent and young adult age spectrum. Hematology Am. Soc. Hematol. Educ. Program 2016, 2016, 589-597. [CrossRef] [PubMed]

6. Miles, R.R.; Arnold, S.; Cairo, M.S. Risk factors and treatment of childhood and adolescent Burkitt lymphoma/leukaemia. Br. J. Haematol. 2012, 156, 730-743. [CrossRef]

7. Advani, R.; Flinn, I.; Popplewell, L.; Forero, A.; Bartlett, N.L.; Ghosh, N.; Kline, J.; Roschewski, M.; LaCasce, A.; Collins, G.P.; et al. CD47 Blockade by Hu5F9-G4 and Rituximab in Non-Hodgkin's Lymphoma. N. Engl. J. Med. 2018, 379, 1711-1721. [CrossRef]

8. Bonavida, B. Postulated mechanisms of resistance of B-cell non-Hodgkin lymphoma to rituximab treatment regimens: strategies to overcome resistance. Semin. Oncol. 2014, 41, 667-677. [CrossRef]

9. Kerjaschki, D.; Sharkey, D.J.; Farquhar, M.G. Identification and characterization of podocalyxin-the major sialoprotein of the renal glomerular epithelial cell. J. Cell Biol. 1984, 98, 1591-1596. [CrossRef]

10. Horvat, R.; Hovorka, A.; Dekan, G.; Poczewski, H.; Kerjaschki, D. Endothelial cell membranes contain podocalyxin — the major sialoprotein of visceral glomerular epithelial cells. J. Cell Biol. 1986, 102, 484-491. [CrossRef]

11. Doyonnas, R.; Nielsen, J.S.; Chelliah, S.; Drew, E.; Hara, T.; Miyajima, A.; McNagny, K.M. Podocalyxin is a CD34-related marker of murine hematopoietic stem cells and embryonic erythroid cells. Blood 2005, 105, 4170-4178. [CrossRef] [PubMed] 
12. Vitureira, N.; McNagny, K.; Soriano, E.; Burgaya, F. Pattern of expression of the podocalyxin gene in the mouse brain during development. Gene Expr. Patterns 2005, 5, 349-354. [CrossRef] [PubMed]

13. Miettinen, A.; Solin, M.L.; Reivinen, J.; Juvonen, E.; Vaisanen, R.; Holthofer, H. Podocalyxin in rat platelets and megakaryocytes. Am. J. Pathol. 1999, 154, 813-822. [CrossRef]

14. Nielsen, J.S.; McNagny, K.M. The role of podocalyxin in health and disease. J. Am. Soc. Nephrol. 2009, 20, 1669-1676. [CrossRef]

15. Kershaw, D.B.; Beck, S.G.; Wharram, B.L.; Wiggins, J.E.; Goyal, M.; Thomas, P.E.; Wiggins, R.C. Molecular cloning and characterization of human podocalyxin-like protein. Orthologous relationship to rabbit PCLP1 and rat podocalyxin. J. Biol. Chem. 1997, 272, 15708-15714. [CrossRef]

16. Takeda, T. Podocyte cytoskeleton is connected to the integral membrane protein podocalyxin through $\mathrm{Na}+/ \mathrm{H}+-$ exchanger regulatory factor 2 and ezrin. Clin. Exp. Nephrol. 2003, 7, 260-269. [CrossRef]

17. Doyonnas, R.; Kershaw, D.B.; Duhme, C.; Merkens, H.; Chelliah, S.; Graf, T.; McNagny, K.M. Anuria, omphalocele, and perinatal lethality in mice lacking the CD34-related protein podocalyxin. J. Exp. Med. 2001, 194, 13-27. [CrossRef]

18. Sassetti, C.; Tangemann, K.; Singer, M.S.; Kershaw, D.B.; Rosen, S.D. Identification of podocalyxin-like protein as a high endothelial venule ligand for L-selectin: parallels to CD34. J. Exp. Med. 1998, 187, 1965-1975. [CrossRef]

19. Larrucea, S.; Butta, N.; Arias-Salgado, E.G.; Alonso-Martin, S.; Ayuso, M.S.; Parrilla, R. Expression of podocalyxin enhances the adherence, migration, and intercellular communication of cells. Exp. Cell Res. 2008, 314, 2004-2015. [CrossRef]

20. Kerjaschki, D.; Poczewski, H.; Dekan, G.; Horvat, R.; Balzar, E.; Kraft, N.; Atkins, R.C. Identification of a major sialoprotein in the glycocalyx of human visceral glomerular epithelial cells. J. Clin. Invest. 1986, 78, 1142-1149. [CrossRef]

21. Dekan, G.; Gabel, C.; Farquhar, M.G. Sulfate contributes to the negative charge of podocalyxin, the major sialoglycoprotein of the glomerular filtration slits. Proc. Natl. Acad. Sci. USA 1991, 88, 5398-5402. [CrossRef]

22. Somasiri, A.; Nielsen, J.S.; Makretsov, N.; McCoy, M.L.; Prentice, L.; Gilks, C.B.; Chia, S.K.; Gelmon, K.A.; Kershaw, D.B.; Huntsman, D.G.; et al. Overexpression of the anti-adhesin podocalyxin is an independent predictor of breast cancer progression. Cancer Res. 2004, 64, 5068-5073. [CrossRef] [PubMed]

23. Larsson, A.; Johansson, M.E.; Wangefjord, S.; Gaber, A.; Nodin, B.; Kucharzewska, P.; Welinder, C.; Belting, M.; Eberhard, J.; Johnsson, A.; et al. Overexpression of podocalyxin-like protein is an independent factor of poor prognosis in colorectal cancer. Br. J. Cancer 2011, 105, 666-672. [CrossRef] [PubMed]

24. Casey, G.; Neville, P.J.; Liu, X.; Plummer, S.J.; Cicek, M.S.; Krumroy, L.M.; Curran, A.P.; McGreevy, M.R.; Catalona, W.J.; Klein, E.A.; et al. Podocalyxin variants and risk of prostate cancer and tumor aggressiveness. Hum. Mol. Genet. 2006, 15, 735-741. [CrossRef] [PubMed]

25. Cipollone, J.A.; Graves, M.L.; Kobel, M.; Kalloger, S.E.; Poon, T.; Gilks, C.B.; McNagny, K.M.; Roskelley, C.D. The anti-adhesive mucin podocalyxin may help initiate the transperitoneal metastasis of high grade serous ovarian carcinoma. Clin. Exp. Metastasis 2012, 29, 239-252. [CrossRef] [PubMed]

26. Hsu, Y.H.; Lin, W.L.; Hou, Y.T.; Pu, Y.S.; Shun, C.T.; Chen, C.L.; Wu, Y.Y.; Chen, J.Y.; Chen, T.H.; Jou, T.S. Podocalyxin EBP50 ezrin molecular complex enhances the metastatic potential of renal cell carcinoma through recruiting Rac1 guanine nucleotide exchange factor ARHGEF7. Am. J. Pathol. 2010, 176, 3050-3061. [CrossRef]

27. Tamayo-Orbegozo, E.; Amo, L.; Rinon, M.; Nieto, N.; Amutio, E.; Maruri, N.; Solaun, M.; Arrieta, A.; Larrucea, S. Podocalyxin promotes proliferation and survival in mature B-cell non-Hodgkin lymphoma cells. Oncotarget 2017, 8, 99722-99739. [CrossRef]

28. Kelley, T.W.; Huntsman, D.; McNagny, K.M.; Roskelley, C.D.; Hsi, E.D. Podocalyxin: a marker of blasts in acute leukemia. Am. J. Clin. Pathol. 2005, 124, 134-142. [CrossRef]

29. Riccioni, R.; Calzolari, A.; Biffoni, M.; Senese, M.; Riti, V.; Petrucci, E.; Pasquini, L.; Cedrone, M.; Lo-Coco, F.; Diverio, D.; et al. Podocalyxin is expressed in normal and leukemic monocytes. Blood Cells Mol. Dis. 2006, 37, 218-225. [CrossRef]

30. Schopperle, W.M.; Kershaw, D.B.; DeWolf, W.C. Human embryonal carcinoma tumor antigen, Gp200/GCTM-2, is podocalyxin. Biochem. Biophys. Res. Commun. 2003, 300, 285-290. [CrossRef]

31. Gregoire, M.; Schopperle, W.M.; DeWolf, W.C. Distinct glycoforms of a tumor specific glycoprotein, gp200, in human testis and testicular tumors. J. Urol. 1995, 154, 275-277. [CrossRef] 
32. Cheung, H.H.; Davis, A.J.; Lee, T.L.; Pang, A.L.; Nagrani, S.; Rennert, O.M.; Chan, W.Y. Methylation of an intronic region regulates miR-199a in testicular tumor malignancy. Oncogene 2011, 30, 3404-3415. [CrossRef] [PubMed]

33. Ney, J.T.; Zhou, H.; Sipos, B.; Buttner, R.; Chen, X.; Kloppel, G.; Gutgemann, I. Podocalyxin-like protein 1 expression is useful to differentiate pancreatic ductal adenocarcinomas from adenocarcinomas of the biliary and gastrointestinal tracts. Hum. Pathol. 2007, 38, 359-364. [CrossRef] [PubMed]

34. Dallas, M.R.; Chen, S.H.; Streppel, M.M.; Sharma, S.; Maitra, A.; Konstantopoulos, K. Sialofucosylated podocalyxin is a functional E- and L-selectin ligand expressed by metastatic pancreatic cancer cells. Am. J. Physiol. Cell Physiol. 2012, 303, C616-C624. [CrossRef] [PubMed]

35. Saukkonen, K.; Hagstrom, J.; Mustonen, H.; Juuti, A.; Nordling, S.; Fermer, C.; Nilsson, O.; Seppanen, H.; Haglund, C. Podocalyxin Is a Marker of Poor Prognosis in Pancreatic Ductal Adenocarcinoma. PLoS ONE 2015, 10, e0129012. [CrossRef] [PubMed]

36. Hayatsu, N.; Kaneko, M.K.; Mishima, K.; Nishikawa, R.; Matsutani, M.; Price, J.E.; Kato, Y. Podocalyxin expression in malignant astrocytic tumors. Biochem. Biophys. Res. Commun. 2008, 374, 394-398. [CrossRef] [PubMed]

37. Koch, L.K.; Zhou, H.; Ellinger, J.; Biermann, K.; Holler, T.; von Rucker, A.; Buttner, R.; Gutgemann, I. Stem cell marker expression in small cell lung carcinoma and developing lung tissue. Hum. Pathol. 2008, 39, 1597-1605.

38. Yamada, S.; Itai, S.; Kaneko, M.K.; Kato, Y. Anti-Podocalyxin Monoclonal Antibody 47-mG2a Detects Lung Cancers by Immunohistochemistry. Monoclon. Antib. Immunodiagn. Immunother. 2018, 37, 91-94. [CrossRef]

39. Yasuoka, H.; Tsujimoto, M.; Hirokawa, M.; Tori, M.; Nakahara, M.; Miyauchi, A.; Kodama, R.; Sanke, T.; Nakamura, Y. Podocalyxin expression in undifferentiated thyroid carcinomas. J. Clin. Pathol. 2008, 61, 1228-1229.

40. Larsson, A.; Fridberg, M.; Gaber, A.; Nodin, B.; Leveen, P.; Jonsson, G.; Uhlen, M.; Birgisson, H.; Jirstrom, K. Validation of podocalyxin-like protein as a biomarker of poor prognosis in colorectal cancer. BMC Cancer 2012, 12, 282. [CrossRef]

41. Larsson, A.H.; Nodin, B.; Syk, I.; Palmquist, I.; Uhlen, M.; Eberhard, J.; Jirstrom, K. Podocalyxin-like protein expression in primary colorectal cancer and synchronous lymph node metastases. Diagn. Pathol. 2013, 8, 109. [CrossRef] [PubMed]

42. Kaprio, T.; Fermer, C.; Hagstrom, J.; Mustonen, H.; Bockelman, C.; Nilsson, O.; Haglund, C. Podocalyxin is a marker of poor prognosis in colorectal cancer. BMC Cancer 2014, 14, 493. [CrossRef] [PubMed]

43. Yasuoka, H.; Tsujimoto, M.; Inagaki, M.; Kodama, R.; Tsuji, H.; Iwahashi, Y.; Mabuchi, Y.; Ino, K.; Sanke, T.; Nakamura, Y. Clinicopathological significance of podocalyxin and phosphorylated ezrin in uterine endometrioid adenocarcinoma. J. Clin. Pathol. 2012, 65, 399-402. [CrossRef] [PubMed]

44. Boman, K.; Larsson, A.H.; Segersten, U.; Kuteeva, E.; Johannesson, H.; Nodin, B.; Eberhard, J.; Uhlen, M.; Malmstrom, P.U.; Jirstrom, K. Membranous expression of podocalyxin-like protein is an independent factor of poor prognosis in urothelial bladder cancer. Br. J. Cancer 2013, 108, 2321-2328. [CrossRef] [PubMed]

45. Binder, Z.A.; Siu, I.M.; Eberhart, C.G.; Ap Rhys, C.; Bai, R.Y.; Staedtke, V.; Zhang, H.; Smoll, N.R.; Piantadosi, S.; Piccirillo, S.G.; et al. Podocalyxin-like protein is expressed in glioblastoma multiforme stem-like cells and is associated with poor outcome. PLOS ONE 2013, 8. [CrossRef] [PubMed]

46. Lin, C.W.; Sun, M.S.; Wu, H.C. Podocalyxin-like 1 is associated with tumor aggressiveness and metastatic gene expression in human oral squamous cell carcinoma. Int. J. Oncol. 2014, 45, 710-718. [CrossRef] [PubMed]

47. Itai, S.; Yamada, S.; Kaneko, M.K.; Harada, H.; Kato, Y. Immunohistochemical Analysis Using Antipodocalyxin Monoclonal Antibody PcMab-47 Demonstrates Podocalyxin Expression in Oral Squamous Cell Carcinomas. Monoclon. Antib. Immunodiagn. Immunother. 2017, 36, 220-223. [CrossRef]

48. Flores-Tellez, T.N.; Lopez, T.V.; Vasquez Garzon, V.R.; Villa-Trevino, S. Co-Expression of Ezrin-CLIC5-Podocalyxin Is Associated with Migration and Invasiveness in Hepatocellular Carcinoma. PLoS ONE 2015, 10. [CrossRef]

49. Laitinen, A.; Bockelman, C.; Hagstrom, J.; Kokkola, A.; Fermer, C.; Nilsson, O.; Haglund, C. Podocalyxin as a Prognostic Marker in Gastric Cancer. PLoS ONE 2015, 10. [CrossRef] 
50. Borg, D.; Hedner, C.; Nodin, B.; Larsson, A.; Johnsson, A.; Eberhard, J.; Jirstrom, K. Expression of podocalyxin-like protein is an independent prognostic biomarker in resected esophageal and gastric adenocarcinoma. BMC Clin. Pathol. 2016, 16. [CrossRef]

51. Zhang, J.; Zhu, Z.; Wu, H.; Yu, Z.; Rong, Z.; Luo, Z.; Xu, Y.; Huang, K.; Qiu, Z.; Huang, C. PODXL, negatively regulated by KLF4, promotes the EMT and metastasis and serves as a novel prognostic indicator of gastric cancer. Gastric Cancer 2019, 22, 48-59. [CrossRef] [PubMed]

52. Zhi, Q.; Chen, H.; Liu, F.; Han, Y.; Wan, D.; Xu, Z.; Kuang, Y.; Zhou, J. Podocalyxin-like protein promotes gastric cancer progression through interacting with RUN and FYVE domain containing 1 protein. Cancer Sci. 2019, 110, 118-134. [CrossRef] [PubMed]

53. Heath, E.I.; Heilbrun, L.K.; Smith, D.; Schopperle, W.M.; Ju, Y.; Bolton, S.; Ahmed, Q.; Sakr, W.A. Overexpression of the Pluripotent Stem Cell Marker Podocalyxin in Prostate Cancer. Anticancer Res. 2018, 38, 6361-6366. [CrossRef] [PubMed]

54. Lee, W.Y.; Kuo, C.C.; Lin, B.X.; Cheng, C.H.; Chen, K.C.; Lin, C.W. Podocalyxin-Like Protein 1 Regulates TAZ Signaling and Stemness Properties in Colon Cancer. Int. J. Mol. Sci. 2017, 18. [CrossRef] [PubMed]

55. Boman, K.; Andersson, G.; Wennersten, C.; Nodin, B.; Ahlgren, G.; Jirstrom, K. Podocalyxin-like and RNA-binding motif protein 3 are prognostic biomarkers in urothelial bladder cancer: a validatory study. Biomark Res. 2017, 5. [CrossRef] [PubMed]

56. Heby, M.; Elebro, J.; Nodin, B.; Jirstrom, K.; Eberhard, J. Prognostic and predictive significance of podocalyxin-like protein expression in pancreatic and periampullary adenocarcinoma. BMC Clin. Pathol. 2015, 15, 10. [CrossRef]

57. Kerosuo, L.; Juvonen, E.; Alitalo, R.; Gylling, M.; Kerjaschki, D.; Miettinen, A. Podocalyxin in human haematopoietic cells. Br. J. Haematol. 2004, 124, 809-818. [CrossRef]

58. Menssen, H.D.; Renkl, H.J.; Rodeck, U.; Maurer, J.; Notter, M.; Schwartz, S.; Reinhardt, R.; Thiel, E. Presence of Wilms' tumor gene (wt1) transcripts and the WT1 nuclear protein in the majority of human acute leukemias. Leukemia 1995, 9, 1060-1067.

59. Almond, L.M.; Charalampakis, M.; Ford, S.J.; Gourevitch, D.; Desai, A. Myeloid Sarcoma: Presentation, Diagnosis, and Treatment. Clin. Lymphoma Myeloma Leuk. 2017, 17, 263-267. [CrossRef]

60. Favreau, A.J.; Cross, E.L.; Sathyanarayana, P. miR-199b-5p directly targets PODXL and DDR1 and decreased levels of miR-199b-5p correlate with elevated expressions of PODXL and DDR1 in acute myeloid leukemia. Am. J. Hematol. 2012, 87, 442-446. [CrossRef]

61. Kershaw, D.B.; Wiggins, J.E.; Wharram, B.L.; Wiggins, R.C. Assignment of the human podocalyxin-like protein (PODXL) gene to 7q32-q33. Genomics 1997, 45, 239-240. [CrossRef] [PubMed]

62. Neville, P.J.; Conti, D.V.; Paris, P.L.; Levin, H.; Catalona, W.J.; Suarez, B.K.; Witte, J.S.; Casey, G. Prostate cancer aggressiveness locus on chromosome 7q32-q33 identified by linkage and allelic imbalance studies. Neoplasia 2002, 4, 424-431. [CrossRef] [PubMed]

63. Cheung, K.J.; Shah, S.P.; Steidl, C.; Johnson, N.; Relander, T.; Telenius, A.; Lai, B.; Murphy, K.P.; Lam, W.; Al-Tourah, A.J.; et al. Genome-wide profiling of follicular lymphoma by array comparative genomic hybridization reveals prognostically significant DNA copy number imbalances. Blood 2009, 113, 137-148. [CrossRef] [PubMed]

64. Garcia, J.L.; Hernandez, J.M.; Gutierrez, N.C.; Flores, T.; Gonzalez, D.; Calasanz, M.J.; Martinez-Climent, J.A.; Piris, M.A.; Lopez-Capitan, C.; Gonzalez, M.B.; et al. Abnormalities on 1q and 7q are associated with poor outcome in sporadic Burkitt's lymphoma. A cytogenetic and comparative genomic hybridization study. Leukemia 2003, 17, 2016-2024. [CrossRef] [PubMed]

65. Palmer, R.E.; Kotsianti, A.; Cadman, B.; Boyd, T.; Gerald, W.; Haber, D.A. WT1 regulates the expression of the major glomerular podocyte membrane protein Podocalyxin. Curr. Biol. 2001, 11, 1805-1809. [CrossRef]

66. Butta, N.; Larrucea, S.; Alonso, S.; Rodriguez, R.B.; Arias-Salgado, E.G.; Ayuso, M.S.; Gonzalez-Manchon, C.; Parrilla, R. Role of transcription factor $\mathrm{Sp} 1$ and $\mathrm{CpG}$ methylation on the regulation of the human podocalyxin gene promoter. BMC Mol. Biol. 2006, 7, 17. [CrossRef]

67. Van Driessche, A.; Berneman, Z.N.; Van Tendeloo, V.F. Active specific immunotherapy targeting the Wilms' tumor protein 1 (WT1) for patients with hematological malignancies and solid tumors: Lessons from early clinical trials. Oncologist 2012, 17, 250-259. [CrossRef] 
68. Archer, M.C. Role of sp transcription factors in the regulation of cancer cell metabolism. Genes Cancer 2011, 2, 712-719. [CrossRef]

69. Stanhope-Baker, P.; Kessler, P.M.; Li, W.; Agarwal, M.L.; Williams, B.R. The Wilms tumor suppressor-1 target gene podocalyxin is transcriptionally repressed by p53. J. Biol. Chem. 2004, 279, 33575-33585. [CrossRef]

70. Wang, D.; Li, Y.; Wu, C.; Liu, Y. PINCH1 is transcriptional regulator in podocytes that interacts with WT1 and represses podocalyxin expression. PLoS ONE 2011, 6. [CrossRef]

71. Favreau, A.J.; McGlauflin, R.E.; Duarte, C.W.; Sathyanarayana, P. miR-199b, a novel tumor suppressor miRNA in acute myeloid leukemia with prognostic implications. Exp. Hematol. Oncol. 2015, 5, 4. [CrossRef] [PubMed]

72. Alberghini, F.; Petrocelli, V.; Rahmat, M.; Casola, S. An epigenetic view of B-cell disorders. Immunol. Cell Biol. 2015, 93, 253-260. [CrossRef] [PubMed]

73. Zheng, B.; Xi, Z.; Liu, R.; Yin, W.; Sui, Z.; Ren, B.; Miller, H.; Gong, Q.; Liu, C. The Function of MicroRNAs in B-Cell Development, Lymphoma and Their Potential in Clinical Practice. Front. Immunol. 2018, 9, 936. [CrossRef] [PubMed]

74. Lawrie, C.H.; Chi, J.; Taylor, S.; Tramonti, D.; Ballabio, E.; Palazzo, S.; Saunders, N.J.; Pezzella, F.; Boultwood, J.; Wainscoat, J.S.; et al. Expression of microRNAs in diffuse large B cell lymphoma is associated with immunophenotype, survival and transformation from follicular lymphoma. J. Cell. Mol. Med. 2009, 13, 1248-1260. [CrossRef] [PubMed]

75. Liu, Y.; Yang, L.; Liu, B.; Jiang, Y.G. Podocalyxin promotes glioblastoma multiforme cell invasion and proliferation via beta-catenin signaling. PLOS ONE 2014, 9. [CrossRef]

76. Liu, B.; Liu, Y.; Jiang, Y. Podocalyxin promotes glioblastoma multiforme cell invasion and proliferation by inhibiting angiotensin-(1-7)/Mas signaling. Oncol. Rep. 2015, 33, 2583-2591. [CrossRef] [PubMed]

77. Zhang, J.; Zhu, Z.; Sheng, J.; Yu, Z.; Yao, B.; Huang, K.; Zhou, L.; Qiu, Z.; Huang, C. miR-509-3-5P inhibits the invasion and lymphatic metastasis by targeting PODXL and serves as a novel prognostic indicator for gastric cancer. Oncotarget 2017, 8, 34867-34883. [CrossRef]

78. Xu, Y.; Pan, Z.G.; Shu, L.; Li, Q.J. Podocalyxin-like, targeted by miR-138, promotes colorectal cancer cell proliferation, migration, invasion and EMT. Eur. Rev. Med. Pharmacol. Sci. 2018, 22, 8664-8674.

79. Itai, S.; Yamada, S.; Kaneko, M.K.; Sano, M.; Nakamura, T.; Yanaka, M.; Handa, S.; Hisamatsu, K.; Nakamura, Y.; Furusawa, Y.; et al. Podocalyxin is crucial for the growth of oral squamous cell carcinoma cell line HSC-2. Biochem. Biophys. Rep. 2018, 15, 93-96. [CrossRef]

80. Snyder, K.A.; Hughes, M.R.; Hedberg, B.; Brandon, J.; Hernaez, D.C.; Bergqvist, P.; Cruz, F.; Po, K.; Graves, M.L.; Turvey, M.E.; et al. Podocalyxin enhances breast tumor growth and metastasis and is a target for monoclonal antibody therapy. Breast Cancer Res. 2015, 17, 46. [CrossRef]

81. Frose, J.; Chen, M.B.; Hebron, K.E.; Reinhardt, F.; Hajal, C.; Zijlstra, A.; Kamm, R.D.; Weinberg, R.A. Epithelial-Mesenchymal Transition Induces Podocalyxin to Promote Extravasation via Ezrin Signaling. Cell Rep. 2018, 24, 962-972. [CrossRef] [PubMed]

82. Lin, C.W.; Sun, M.S.; Liao, M.Y.; Chung, C.H.; Chi, Y.H.; Chiou, L.T.; Yu, J.; Lou, K.L.; Wu, H.C. Podocalyxin-like 1 promotes invadopodia formation and metastasis through activation of Rac1/Cdc42/cortactin signaling in breast cancer cells. Carcinogenesis 2014, 35, 2425-2435. [CrossRef] [PubMed]

83. Wong, B.S.; Shea, D.J.; Mistriotis, P.; Tuntithavornwat, S.; Law, R.A.; Bieber, J.M.; Zheng, L.; Konstantopoulos, K. A Direct Podocalyxin-Dynamin-2 Interaction Regulates Cytoskeletal Dynamics to Promote Migration and Metastasis in Pancreatic Cancer Cells. Cancer Res. 2019, 79, 2878-2891. [CrossRef] [PubMed]

84. Graves, M.L.; Cipollone, J.A.; Austin, P.; Bell, E.M.; Nielsen, J.S.; Gilks, C.B.; McNagny, K.M.; Roskelley, C.D. The cell surface mucin podocalyxin regulates collective breast tumor budding. Breast Cancer Res. 2016, 18, 11. [CrossRef] [PubMed]

85. Sizemore, S.; Cicek, M.; Sizemore, N.; Ng, K.P.; Casey, G. Podocalyxin increases the aggressive phenotype of breast and prostate cancer cells in vitro through its interaction with ezrin. Cancer Res. 2007, 67, 6183-6191. [CrossRef] [PubMed]

86. Meng, X.; Ezzati, P.; Wilkins, J.A. Requirement of podocalyxin in TGF-beta induced epithelial mesenchymal transition. PLOS ONE 2011, 6. [CrossRef]

87. Kusumoto, H.; Shintani, Y.; Kanzaki, R.; Kawamura, T.; Funaki, S.; Minami, M.; Nagatomo, I.; Morii, E.; Okumura, M. Podocalyxin influences malignant potential by controlling epithelial-mesenchymal transition in lung adenocarcinoma. Cancer Sci. 2017, 108, 528-535. [CrossRef] 
88. Huang, Z.; Huang, Y.; He, H.; Ni, J. Podocalyxin promotes cisplatin chemoresistance in osteosarcoma cells through phosphatidylinositide 3-kinase signaling. Mol. Med. Rep. 2015, 12, 3916-3922. [CrossRef]

89. Zhou, Y.; Zhang, L.; Pan, H.; Wang, B.; Yan, F.; Fang, X.; Munnee, K.; Tang, Z. Bmi1 essentially mediates podocalyxin-enhanced Cisplatin chemoresistance in oral tongue squamous cell carcinoma. PLOS ONE 2015, 10. [CrossRef]

90. Wu, H.; Yang, L.; Liao, D.; Chen, Y.; Wang, W.; Fang, J. Podocalyxin regulates astrocytoma cell invasion and survival against temozolomide. Exp. Ther. Med. 2013, 5, 1025-1029. [CrossRef]

91. Hoxhaj, G.; Manning, B.D. The PI3K-AKT network at the interface of oncogenic signalling and cancer metabolism. Nature Reviews Cancer 2020, 20, 74-88. [CrossRef] [PubMed]

92. Sheen, M.R.; Marotti, J.D.; Allegrezza, M.J.; Rutkowski, M.; Conejo-Garcia, J.R.; Fiering, S. Constitutively activated PI3K accelerates tumor initiation and modifies histopathology of breast cancer. Oncogenesis 2016, 5, e267. [CrossRef] [PubMed]

93. Sumimoto, S.; Heike, T.; Kanazashi, S.; Shintaku, N.; Jung, E.Y.; Hata, D.; Katamura, K.; Mayumi, M. Involvement of LFA-1/intracellular adhesion molecule-1-dependent cell adhesion in CD40-mediated inhibition of human B lymphoma cell death induced by surface IgM crosslinking. J. Immunol. 1994, 153, 2488-2496.

94. Williams, K.C.; Cepeda, M.A.; Javed, S.; Searle, K.; Parkins, K.M.; Makela, A.V.; Hamilton, A.M.; Soukhtehzari, S.; Kim, Y.; Tuck, A.B.; et al. Invadopodia are chemosensing protrusions that guide cancer cell extravasation to promote brain tropism in metastasis. Oncogene 2019, 38, 3598-3615. [CrossRef]

95. Reymond, N.; d'Agua, B.B.; Ridley, A.J. Crossing the endothelial barrier during metastasis. Nat. Rev. Cancer 2013, 13, 858-870. [CrossRef] [PubMed]

96. Paz, H.; Pathak, N.; Yang, J. Invading one step at a time: the role of invadopodia in tumor metastasis. Oncogene 2014, 33, 4193-4202. [CrossRef]

97. Chao, M.P.; Tang, C.; Pachynski, R.K.; Chin, R.; Majeti, R.; Weissman, I.L. Extranodal dissemination of non-Hodgkin lymphoma requires CD47 and is inhibited by anti-CD47 antibody therapy. Blood 2011, 118, 4890-4901. [CrossRef]

98. Pals, S.T.; de Gorter, D.J.; Spaargaren, M. Lymphoma dissemination: the other face of lymphocyte homing. Blood 2007, 110, 3102-3111. [CrossRef]

99. McNagny, K.M.; Hughes, M.R.; Graves, M.L.; DeBruin, E.J.; Snyder, K.; Cipollone, J.; Turvey, M.; Tan, P.C.; McColl, S.; Roskelley, C.D. Podocalyxin in the Diagnosis and Treatment of Cancer. In Advances in Cancer Management; Mohan, R., Ed.; InTech: Rijeka, Croatia, 2012; pp. 155-194.

100. Teicher, B.A.; Fricker, S.P. CXCL12 (SDF-1)/CXCR4 pathway in cancer. Clin. Cancer Res. 2010, 16, $2927-2931$. [CrossRef]

101. Burger, J.A.; Peled, A. CXCR4 antagonists: targeting the microenvironment in leukemia and other cancers. Leukemia 2009, 23, 43-52. [CrossRef]

102. Lopez-Giral, S.; Quintana, N.E.; Cabrerizo, M.; Alfonso-Perez, M.; Sala-Valdes, M.; De Soria, V.G.; Fernandez-Ranada, J.M.; Fernandez-Ruiz, E.; Munoz, C. Chemokine receptors that mediate B cell homing to secondary lymphoid tissues are highly expressed in B cell chronic lymphocytic leukemia and non-Hodgkin lymphomas with widespread nodular dissemination. J. Leukoc. Biol. 2004, 76, 462-471. [CrossRef] [PubMed]

103. Beider, K.; Ribakovsky, E.; Abraham, M.; Wald, H.; Weiss, L.; Rosenberg, E.; Galun, E.; Avigdor, A.; Eizenberg, O.; Peled, A.; et al. Targeting the CD20 and CXCR4 pathways in non-hodgkin lymphoma with rituximab and high-affinity CXCR4 antagonist BKT140. Clin. Cancer Res. 2013, 19, 3495-3507. [CrossRef] [PubMed]

104. Moreno, M.J.; Bosch, R.; Dieguez-Gonzalez, R.; Novelli, S.; Mozos, A.; Gallardo, A.; Pavon, M.A.; Cespedes, M.V.; Granena, A.; Alcoceba, M.; et al. CXCR4 expression enhances diffuse large B cell lymphoma dissemination and decreases patient survival. J. Pathol. 2015, 235, 445-455. [CrossRef] [PubMed]

105. Bertolini, F.; Dell'Agnola, C.; Mancuso, P.; Rabascio, C.; Burlini, A.; Monestiroli, S.; Gobbi, A.; Pruneri, G.; Martinelli, G. CXCR4 neutralization, a novel therapeutic approach for non-Hodgkin's lymphoma. Cancer Res. 2002, 62, 3106-3112.

106. Zhong, L.; Simoneau, B.; Huot, J.; Simard, M.J. p38 and JNK pathways control E-selectin-dependent extravasation of colon cancer cells by modulating miR-31 transcription. Oncotarget 2017, 8, 1678-1687. [CrossRef] 
107. Nonomura, C.; Kikuchi, J.; Kiyokawa, N.; Ozaki, H.; Mitsunaga, K.; Ando, H.; Kanamori, A.; Kannagi, R.; Fujimoto, J.; Muroi, K.; et al. CD43, but not P-selectin glycoprotein ligand-1, functions as an E-selectin counter-receptor in human pre-B-cell leukemia NALL-1. Cancer Res. 2008, 68, 790-799. [CrossRef]

108. Ye, X.; Weinberg, R.A. Epithelial-Mesenchymal Plasticity: A Central Regulator of Cancer Progression. Trends Cell Biol. 2015, 25, 675-686. [CrossRef]

109. Kalluri, R.; Weinberg, R.A. The basics of epithelial-mesenchymal transition. J. Clin. Invest. 2009, 119, 1420-1428. [CrossRef]

110. Kahlert, U.D.; Joseph, J.V.; Kruyt, F.A.E. EMT- and MET-related processes in nonepithelial tumors: importance for disease progression, prognosis, and therapeutic opportunities. Mol. Oncol. 2017, 11, 860-877. [CrossRef]

111. Chen, S.C.; Liao, T.T.; Yang, M.H. Emerging roles of epithelial-mesenchymal transition in hematological malignancies. J. Biomed. Sci. 2018, 25, 37. [CrossRef]

112. Lemma, S.; Karihtala, P.; Haapasaari, K.M.; Jantunen, E.; Soini, Y.; Bloigu, R.; Pasanen, A.K.; Turpeenniemi-Hujanen, T.; Kuittinen, O. Biological roles and prognostic values of the epithelial-mesenchymal transition-mediating transcription factors Twist, ZEB1 and Slug in diffuse large B-cell lymphoma. Histopathology 2013, 62, 326-333. [CrossRef] [PubMed]

113. Zhao, L.; Liu, Y.; Zhang, J.; Qi, Q. LncRNA SNHG14/miR-5590-3p/ZEB1 positive feedback loop promoted diffuse large B cell lymphoma progression and immune evasion through regulating PD-1/PD-L1 checkpoint. Cell Death Dis. 2019, 10, 731. [CrossRef]

114. Sanchez-Tillo, E.; Fanlo, L.; Siles, L.; Montes-Moreno, S.; Moros, A.; Chiva-Blanch, G.; Estruch, R.; Martinez, A.; Colomer, D.; Gyorffy, B.; et al. The EMT activator ZEB1 promotes tumor growth and determines differential response to chemotherapy in mantle cell lymphoma. Cell Death Differ. 2014, 21, 247-257. [CrossRef] [PubMed]

115. Yamasaki, S.; Tanimoto, K.; Kohno, K.; Kadowaki, M.; Takase, K.; Kondo, S.; Kubota, A.; Takeshita, M.; Okamura, S. UGT1A1 *6 polymorphism predicts outcome in elderly patients with relapsed or refractory diffuse large B-cell lymphoma treated with carboplatin, dexamethasone, etoposide and irinotecan. Ann. Hematol. 2015, 94, 65-69. [CrossRef] [PubMed]

116. Saotome, T.; Takagi, T.; Sakai, C.; Kumagai, K.; Tamaru, J. Combination chemotherapy with irinotecan and adriamycin for refractory and relapsed non-Hodgkin's lymphoma. Ann. Oncol. 2000, 11, 115-116. [CrossRef]

117. Dasari, S.; Tchounwou, P.B. Cisplatin in cancer therapy: molecular mechanisms of action. Eur. J. Pharmacol. 2014, 740, 364-378. [CrossRef]

118. Ho, K.G.; Grommes, C. Molecular profiling of primary central nervous system lymphomas - predictive and prognostic value. Curr. Opin. Neurol. 2019, 32, 886-894. [CrossRef]

119. Sionov, R.V.; Spokoini, R.; Kfir-Erenfeld, S.; Cohen, O.; Yefenof, E. Mechanisms regulating the susceptibility of hematopoietic malignancies to glucocorticoid-induced apoptosis. Adv. Cancer. Res. 2008, 101, 127-248.

120. Kfir-Erenfeld, S.; Sionov, R.V.; Spokoini, R.; Cohen, O.; Yefenof, E. Protein kinase networks regulating glucocorticoid-induced apoptosis of hematopoietic cancer cells: fundamental aspects and practical considerations. Leuk. Lymphoma 2010, 51, 1968-2005. [CrossRef]

121. Pui, C.H.; Evans, W.E. Treatment of acute lymphoblastic leukemia. N. Engl. J. Med. 2006, 354, $166-178$. [CrossRef]

122. Tome, M.E.; Jaramillo, M.C.; Briehl, M.M. Hydrogen peroxide signaling is required for glucocorticoid-induced apoptosis in lymphoma cells. Free Radic. Biol. Med. 2011, 51, 2048-2059. [CrossRef] [PubMed]

123. Lombard, D.B.; Chua, K.F.; Mostoslavsky, R.; Franco, S.; Gostissa, M.; Alt, F.W. DNA repair, genome stability, and aging. Cell 2005, 120, 497-512. [CrossRef] [PubMed]

124. Mössner, E.; Brünker, P.; Moser, S.; Püntener, U.; Schmidt, C.; Herter, S.; Grau, R.; Gerdes, C.; Nopora, A.; van Puijenbroek, E.; et al. Increasing the efficacy of CD20 antibody therapy through the engineering of a new type II anti-CD20 antibody with enhanced direct and immune effector cell-mediated B-cell cytotoxicity. Blood 2010, 115, 4393-4402. [CrossRef] [PubMed]

125. Niederfellner, G.; Lammens, A.; Mundigl, O.; Georges, G.J.; Schaefer, W.; Schwaiger, M.; Franke, A.; Wiechmann, K.; Jenewein, S.; Slootstra, J.W.; et al. Epitope characterization and crystal structure of GA101 provide insights into the molecular basis for type I/II distinction of CD20 antibodies. Blood 2011, 118, 358-367. [CrossRef] 
126. Alduaij, W.; Ivanov, A.; Honeychurch, J.; Cheadle, E.J.; Potluri, S.; Lim, S.H.; Shimada, K.; Chan, C.H.T.; Tutt, A.; Beers, S.A.; et al. Novel type II anti-CD20 monoclonal antibody (GA101) evokes homotypic adhesion and actin-dependent, lysosome-mediated cell death in B-cell malignancies. Blood 2011, 117, 4519-4529. [CrossRef] [PubMed]

127. Cairns, R.A.; Harris, I.S.; Mak, T.W. Regulation of cancer cell metabolism. Nat. Rev. Cancer. 2011, 11, 85-95. [CrossRef]

128. Kedia-Mehta, N.; Finlay, D.K. Competition for nutrients and its role in controlling immune responses. Nat. Commun. 2019, 10, 2123. [CrossRef]

129. Cao, Y. Adipocyte and lipid metabolism in cancer drug resistance. J. Clin. Invest. 2019, 129, $3006-3017$. [CrossRef]

130. Martinez-Outschoorn, U.E.; Peiris-Pages, M.; Pestell, R.G.; Sotgia, F.; Lisanti, M.P. Cancer metabolism: a therapeutic perspective. Nat. Rev. Clin. Oncol. 2017, 14, 11-31. [CrossRef]

131. DeBerardinis, R.J.; Cheng, T. Q's next: the diverse functions of glutamine in metabolism, cell biology and cancer. Oncogene 2010, 29, 313-324. [CrossRef]

132. Wise, D.R.; Thompson, C.B. Glutamine addiction: a new therapeutic target in cancer. Trends Biochem. Sci. 2010, 35, 427-433. [CrossRef] [PubMed]

133. Le, A.; Lane, A.N.; Hamaker, M.; Bose, S.; Gouw, A.; Barbi, J.; Tsukamoto, T.; Rojas, C.J.; Slusher, B.S.; Zhang, H.; et al. Glucose-independent glutamine metabolism via TCA cycling for proliferation and survival in B cells. Cell Metab. 2012, 15, 110-121. [CrossRef] [PubMed]

134. Schopperle, W.M.; Lee, J.M.; Dewolf, W.C. The human cancer and stem cell marker podocalyxin interacts with the glucose-3-transporter in malignant pluripotent stem cells. Biochem. Biophys. Res. Commun. 2010, 398, 372-376. [CrossRef] [PubMed]

135. Economou, C.G.; Kitsiou, P.V.; Tzinia, A.K.; Panagopoulou, E.; Marinos, E.; Kershaw, D.B.; Kerjaschki, D.; Tsilibary, E.C. Enhanced podocalyxin expression alters the structure of podocyte basal surface. J. Cell Sci. 2004, 117, 3281-3294. [CrossRef] [PubMed]

136. Tsotakos, N.E.; Sagnou, M.; Kotsopoulou, E.S.; Tsilibary, E.C.; Drossopoulou, G.I. Glucose-induced gradual phenotypic modulation of cultured human glomerular epithelial cells may be independent of Wilms' tumor 1 (WT1). BMC Cell Biol. 2013, 14, 28. [CrossRef]

137. Thangavelu, K.; Pan, C.Q.; Karlberg, T.; Balaji, G.; Uttamchandani, M.; Suresh, V.; Schuler, H.; Low, B.C.; Sivaraman, J. Structural basis for the allosteric inhibitory mechanism of human kidney-type glutaminase (KGA) and its regulation by Raf-Mek-Erk signaling in cancer cell metabolism. Proc. Natl. Acad. Sci. USA 2012, 109, 7705-7710. [CrossRef]

138. Gao, M.; Liang, J.; Lu, Y.; Guo, H.; German, P.; Bai, S.; Jonasch, E.; Yang, X.; Mills, G.B.; Ding, Z. Site-specific activation of AKT protects cells from death induced by glucose deprivation. Oncogene 2014, 33, 745-755. [CrossRef]

139. Zhang, F.; Du, G. Dysregulated lipid metabolism in cancer. World J. Biol. Chem. 2012, 3, 167-174. [CrossRef]

140. Currie, E.; Schulze, A.; Zechner, R.; Walther, T.C.; Farese, R.V. Cellular fatty acid metabolism and cancer. Cell Metab. 2013, 18, 153-161. [CrossRef]

141. Menendez, J.A.; Lupu, R. Fatty acid synthase and the lipogenic phenotype in cancer pathogenesis. Nat. Rev. Cancer 2007, 7, 763-777. [CrossRef]

142. Ventura, R.; Mordec, K.; Waszczuk, J.; Wang, Z.; Lai, J.; Fridlib, M.; Buckley, D.; Kemble, G.; Heuer, T.S. Inhibition of de novo Palmitate Synthesis by Fatty Acid Synthase Induces Apoptosis in Tumor Cells by Remodeling Cell Membranes, Inhibiting Signaling Pathways, and Reprogramming Gene Expression. EBioMedicine 2015, 2, 808-824. [CrossRef] [PubMed]

143. Rysman, E.; Brusselmans, K.; Scheys, K.; Timmermans, L.; Derua, R.; Munck, S.; Van Veldhoven, P.P.; Waltregny, D.; Daniels, V.W.; Machiels, J.; et al. De novo lipogenesis protects cancer cells from free radicals and chemotherapeutics by promoting membrane lipid saturation. Cancer Res. 2010, 70, 8117-8126. [CrossRef] [PubMed]

144. Ambrosio, M.R.; Piccaluga, P.P.; Ponzoni, M.; Rocca, B.J.; Malagnino, V.; Onorati, M.; De Falco, G.; Calbi, V.; Ogwang, M.; Naresh, K.N.; et al. The alteration of lipid metabolism in Burkitt lymphoma identifies a novel marker: adipophilin. PLoS ONE 2012, 7. [CrossRef] [PubMed]

145. Patra, K.C.; Hay, N. The pentose phosphate pathway and cancer. Trends Biochem. Sci. 2014, 39, 347-354. [CrossRef] [PubMed] 
146. Jiang, P.; Du, W.; Wu, M. Regulation of the pentose phosphate pathway in cancer. Protein Cell 2014, 5, 592-602. [CrossRef] [PubMed]

147. McBrayer, S.K.; Yarrington, M.; Qian, J.; Feng, G.; Shanmugam, M.; Gandhi, V.; Krett, N.L.; Rosen, S.T. Integrative gene expression profiling reveals G6PD-mediated resistance to RNA-directed nucleoside analogues in B-cell neoplasms. PLoS ONE 2012, 7. [CrossRef]

148. Xiao, G.; Chan, L.N.; Klemm, L.; Braas, D.; Chen, Z.; Geng, H.; Zhang, Q.C.; Aghajanirefah, A.; Cosgun, K.N.; Sadras, T.; et al. B-Cell-Specific Diversion of Glucose Carbon Utilization Reveals a Unique Vulnerability in B Cell Malignancies. Cell 2018, 173, 470-484. [CrossRef]

(C) 2020 by the authors. Licensee MDPI, Basel, Switzerland. This article is an open access article distributed under the terms and conditions of the Creative Commons Attribution (CC BY) license (http://creativecommons.org/licenses/by/4.0/). 